\title{
ГИДРОДИНАМИЧЕСКОЕ ОБОСНОВАНИЕ ИЗМЕНЕНИЙ ГИДРОГЕОХИМИЧЕСКИХ УСЛОВИЙ СТРЕЖЕВСКОГО МЕСТОРОЖДЕНИЯ ПОДЗЕМНЫХ ВОД (ТОМСКАЯ ОБЛАСТЬ)
}

\author{
Дутова Екатерина Матвеевна', \\ dutova@tpu.ru
}

\author{
Кузеванов Константин Иванович', \\ kki@tpu.ru
}

\author{
Кузеванов Константин Константинович', \\ kuzevanovkk@tpu.ru \\ 1 Национальный исследовательский Томский политехнический университет, \\ Россия, 634050, г. Томск, пр. Ленина, 30.
}

\begin{abstract}
Актуальность работы связана с необходимостью текущего изучения качества подземных вод, используемых для водоснабжения населения и проблемами изменения химического состава подземных вод при эксплуатации. Эти изменения зависят как от природной ландшафтно-климатической и гидрогеохимической зональности, так и от режима эксплуатации водозабора. Обогащение подземных вод железом за счёт региональных особенностей геохимических условий приводит к неизбежному применению водоподготовки, эффективность которой может существенно изменяться под влиянием водоотбора.

Цель работы: оценить возможное влияние гидродинамических условий, возникающих при длительной эксплуатации крупного водозабора, на изменение качества подземных вод эксплуатируемого месторождения.

Методы. В основу работы положены результаты локального мониторинга на действующем водозаборе за длительный период наблюдений в рамках решения задач эксплуатационной разведки на действующем месторождении подземных вод. Обобщены данные наблюдений за положением статических уровней. Для исследования изменения химического состава подземных вод использованы материалы регулярного гидрогеохимического опробования, выполняющегося на водозаборе в рамках регламента режимных наблюдений, предусмотренных лицензионным соглашением. Количественная оценка процесса перетекания между водоносными горизонтами выполнена при помощи численного гидродинамического моделирования

Результаты. Обработка результатов мониторинговых исследований показала, что в процессе интенсивной эксплуатации подземных вод возникают благоприятные условия для накопления железа в растворенной и трудно извлекаемой форме. Этому способствует образование органоминеральных комплексных соединений железа, плохо поддающихся удалению при стандартной водоподготовке на основе аэрирования. Причину таких техногенных процессов авторы связывают с изменением геохимической обстановки в зоне фильтров эксплуатационных скважин за счет подтягивания с поверхности кислых вод с высокой концентрацией органических соединений.
\end{abstract}

\section{Ключевые слова:}

Месторождение подземных вод, химический состав, мониторинг подземных вод, изменение уровенного и гидрогеохимического режимов, гидродинамическое моделирование фильтрационных процессов.

\section{Введение}

Проблемам эксплуатации месторождений питьевых подземных вод посвящено множество публикаций [1-6]. Зачастую освещаются вопросы влияния водоотбора на характеристики геологической среды [7, 8]. Имеются работы, посвященные оптимизации и сохранению ресурсов эксплуатируемых месторождений под влиянием различных типов граничных условиях [9-17]. Наконец, особое внимание уделяется вопросам качества эксплуатируемых подземных вод [18-26]. Поведению железа, как элемента, зачастую ухудшающего качество вод, посвящено много работ. Это исследования, касающиеся влияния параметров геохимической среды на миграционные процессы [27-33], вопросы технологий водоподготовки [34-40] и минералообразования в пластовых и технологических процессах [41-44] и др.

Цель данной работы заключается в оценке влияния гидродинамических условий на изменения качества подземных вод эксплуатируемых месторождений пластового типа. Для этих типовых условий характерны: сработка упругих запасов напорных вод, большие по площади депрессионные воронки, активизация или формирование процессов перетекания за счёт вышележащих водоносных горизонтов и поверхностных вод.

В данной работе приведены результаты многолетних исследований режима эксплуатации Стрежевского месторождения подземных вод, установлено, что под влиянием работы водозаборных скважин изменяется геохимический облик подземных вод в пластовых условиях. Это может оказывать существенное влияние на устойчивость ионов железа в растворенном состоянии, что способствует снижению эффективности технологии водоподготовки, применяющейся на водозаборе для обработки воды перед подачей потребителям.

Эволюция гидрогеохимической среды рассматривается на примере водозабора г. Стрежевого, эксплуатирующего подземные воды палеогеновых отложений Западно-Сибирского артезианского бассейна. Работа водозабора характеризует типовые условия техногенных процессов, возника- 
ющих при добыче подземных вод хозяйственнопитьевого назначения на многочисленных месторождениях подземных вод, расположенных в ландшафтных условиях средней тайги с повышенной заболоченностью [45]. Оценка характера техногенных изменений состава подземных вод основана на исследовании материалов многолетних режимных наблюдений, которые регулярно проводятся в рамках обязательного мониторинга, регламентированного лицензионным соглашением. Используемая на водозаборе технология водоподготовки основана на физико-химическом процессе аэрации, который способствует активному переходу ионов железа в нерастворимую форму и позволяет существенно снижать их концентрацию в подземных водах, подаваемых в распределительную сеть.

\section{Характеристика Стрежевского месторождения подземных вод}

Стрежевское месторождение подземных вод разведано для организации хозяйственно-питьевого водоснабжения населения одноименного города Стрежевого. Месторождение находится вблизи северо-восточной окраины города. Для эксплуатации используются подземные воды палеогеновых отложений новомихайловской, атлымской и тавдинской свит. Схема водозабора представляет собой площадную систему, которая состоит из 21-й наблюдательной и 17-ти эксплуатационных скважин (рис. 1).

Водозабор существует с 1973 г. За время эксплуатации общий годовой водоотбор изменялся. В период с начала 70-х гг. он составлял около $1096 \mathrm{~m}^{3}$ /сут. Затем повышался до конца 90-х гг., когда максимум составил свыше $12000 \mathrm{~m}^{3} /$ сут. Затем общий водоотбор постепенно снижался, и в настоящее время составляет порядка $5000 \mathrm{~m}^{3} /$ сут.

Общее представление о гидрогеологическом разрезе месторождения показано на рис. 2. Основные эксплуатируемые горизонты отложений атлымской и новомихайловской свиты гидравлически связанные друг с другом, представлены песками с линзами глин, бурых углей и лигнитов. Породы тавдинской свиты, по сравнению с отложениями атлымской и новомихайловской свит, существенно в большей степени обогащены органикой. На глубинах порядка 150-250 м водоносные отложения разделены водоупором многолетнемерзлых пород.

Химический состав вод эксплуатируемых отложений типичен для подземных вод, формирующихся в ландшафтно-климатических условиях средней тайги. Они ультрапресные, умеренно пресные, гидрокарбонатные кальциевые, кальциево-магниевые, умеренно жесткие.

За длительный период работы водозабора по данным АО «Томскгеомониторинг» в эксплуата-

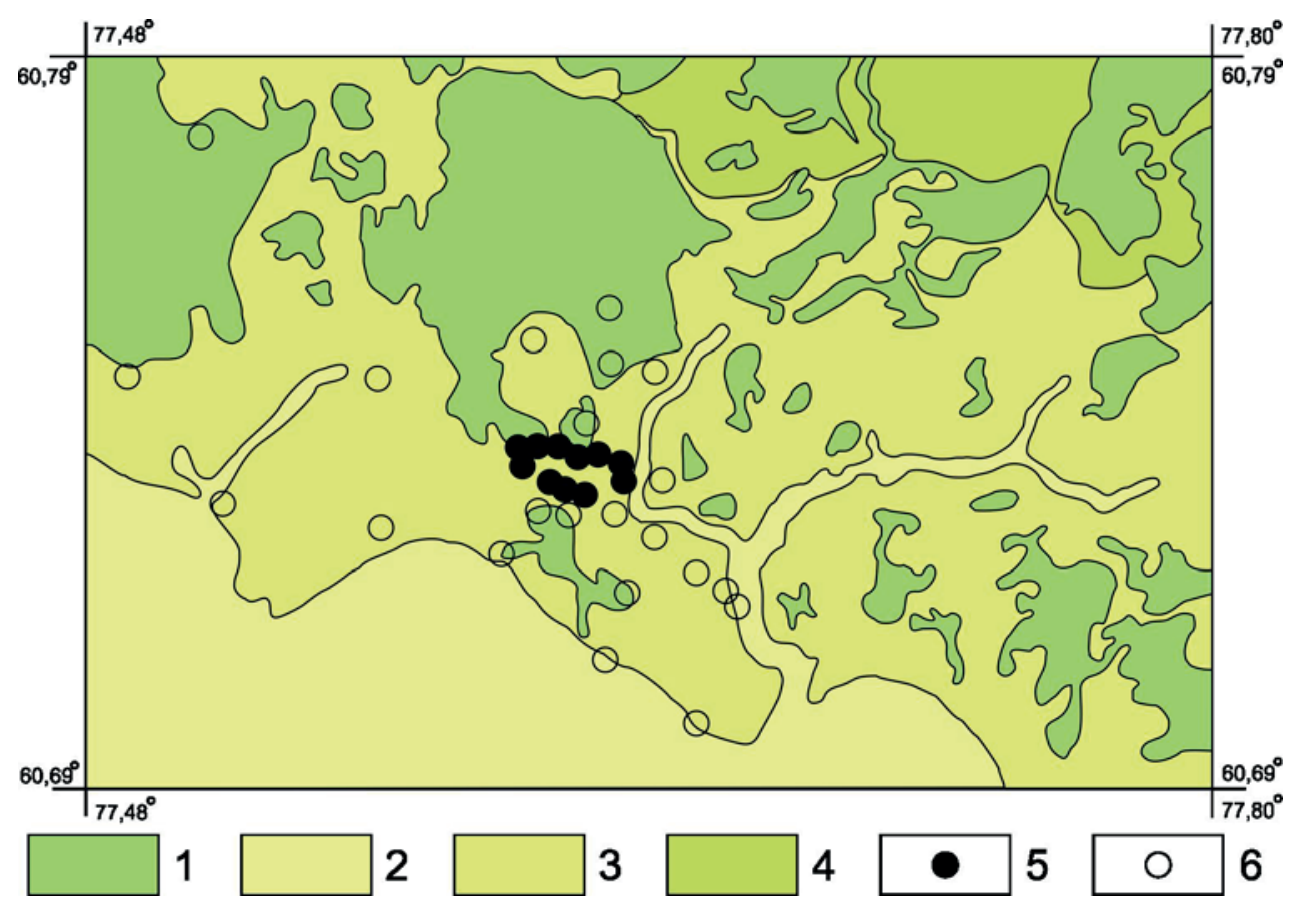

Pис. 1. Схематическая гидрогеологическая карта района Стрежевского месторождения подземных вод: Водоносные горизонты: 1 - современных аллювиальных отложений; 2 - современных болотных отложений; 3 - аллювиальных отложений второй надпойменной террасы; 4 - аллювиальных отложений второй надпойленной террасы. Скважины: 5 - эксплуатационная; 6 - наблюдательная

Fig. 1. Schematic hydrogeological map of underground water deposit in the Strezhevoy field: Aquifers: 1 - modern alluvial deposits; 2 - modern marsh deposits; 3 -alluvial deposits of the second terrace above the flood-plain; 4 -alluvial deposits of the second terrace above the floodplain. Wells: 5 - operational; 6 - observational 


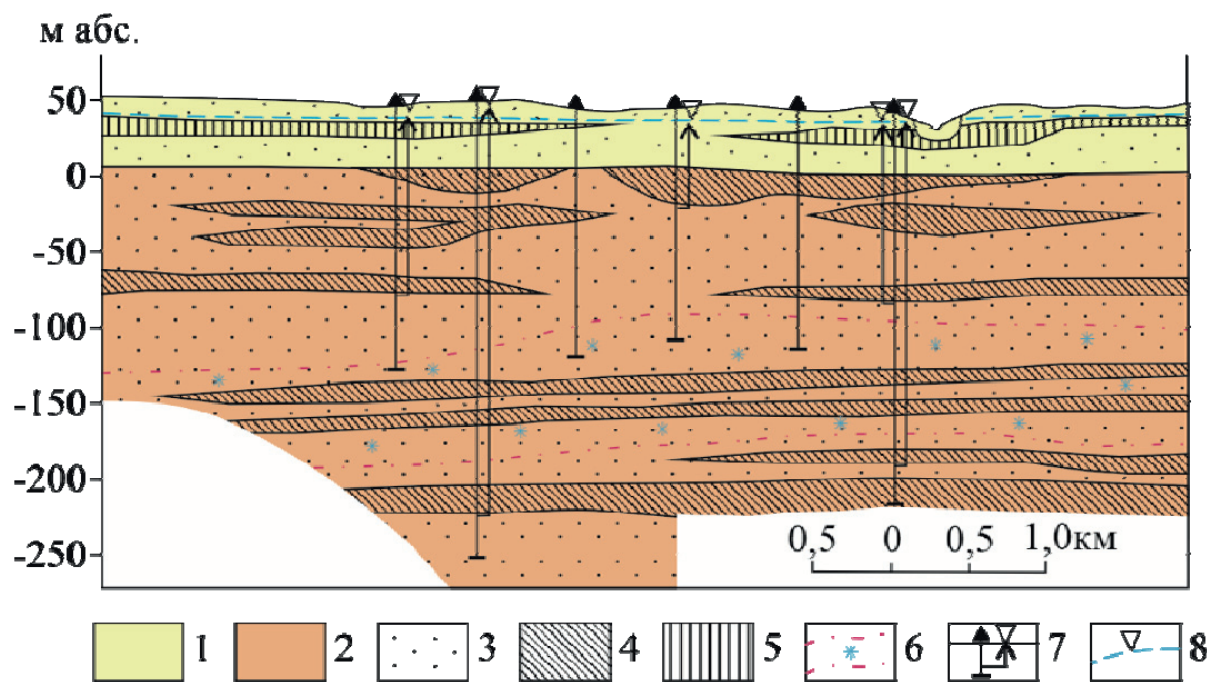

Pис. 2. Схематический разрез Стрежевского месторождения подземных вод: водоносные комплексы: 1 - четвертичных отложений; 2 - палеогеновых отложений; литологический состав: 3 - пески; 4 - глины; 5-суглинки; 6 - многолетнемерзлые породы; 7, 8 эксплуатационные скважины и уровни подземных вод

Fig. 2. Schematic section of underground water deposit in the Strezhevoy field: water-bearing complexes: 1 - quarternary deposits; 2 - paleogene deposits; lithologic structure: 3 - sands; 4 - clays; 5 -loams; 6 - permafrost breeds; 7, 8 -operational wells and levels of underground waters

ционном водоносном комплексе палеогеновых отложений сформировалась депрессионная воронка, границы распространения которой не могут быть точно определены из-за недостаточного количества наблюдательных скважин за пределами площади водозаборного участка. Уменьшение водоотбора сказалось на положении уровня подземных вод эксплуатируемого водоносного комплекса. Так, например, общая сработка пьезометрической поверхности в 2000 г. изменялась по площади водозабора от 1,0 до 6,85 м и уменьшилась по сравнению с предшествующим годом на $0,14-0,71$ м. В верхнем водоносном горизонте верхнеолигоценовых отложений трайгородской свиты и верхнечетвертичных отложений второй надпойменной террасы р. Оби общее снижение уровня в пределах водозабора за этот период изменялось от 0,71 до $1,68 \mathrm{~m}$.

Анализ изменения гидрогеологических условий месторождения подземных вод под влиянием длительной эксплуатации показывает наличие устойчивых тенденций в проявлении гидродинамического и гидрогеохимического режимов подземных вод.

Исходный материал, на основе которого сделаны эти выводы, представлен данными многолетних режимных наблюдений, включающими фактические замеры динамических уровней подземных вод и результаты систематического опробования их химического состава по эксплуатационным и режимным скважинам водозабора.

Динамика изменения уровенного режима подземных вод под воздействием эксплуатации отражает общие закономерности формирования понижения в границах депрессивной воронки и связана с характером изменения нагрузки на водозабор- ные скважины под влиянием водоотбора, то есть полностью объясняется техногенным фактором.

За время работы водозабора отмечается изменение нагрузки на скважины, которое в свою очередь тесно связано с величиной водоотбора и оказывает решающее влияние на динамические уровни пьезометрической поверхности и формирование ее понижения.

В режиме эксплуатации водозабора можно выделить два основных этапа. Первый этап соответствует периоду наращивания фонда эксплуатационных (водозаборных) скважин, заканчившийся в 1989 г. После этого работа водозабора характеризуется активным перераспределением нагрузки между существующими водозаборными скважинами. Иногда отдельные скважины временно выводятся из эксплуатации. По наблюдательным скважинным отмечается интенсивный рост глубины динамических уровней на первом этапе, а на втором этапе достигается некоторая стабилизация депрессионной воронки.

Самые сильные изменения динамических уровней по отдельным эксплуатационным скважинам фиксируются на втором этапе эксплуатации водозабора. В это время работа скважин характеризуется максимальными амплитудами величины действующего напора, интенсифицирующей процессы вертикальных перетоков за счет формирования привлекаемых ресурсов из вышележащего водоносного горизонта неоген-четвертичных отложений.

Эти особенности эксплуатации водозабора оказывают существенное влияние на изменение в химическом составе подземных вод. По данным режимных наблюдений установлена зависимость между изменением концентрации ионов железа 


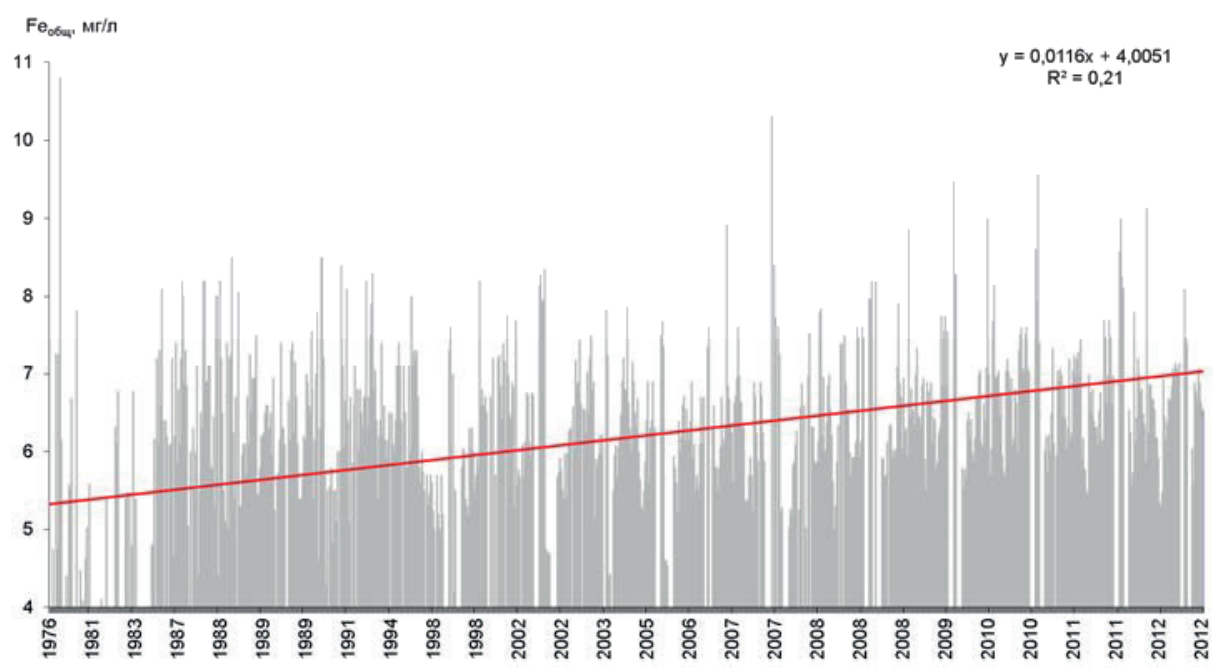

Рис. 3. Изменение содержания железа в подземных водах при эксплуатащии водозабора

Fig. 3. Change of iron content in underground waters at water intake operation

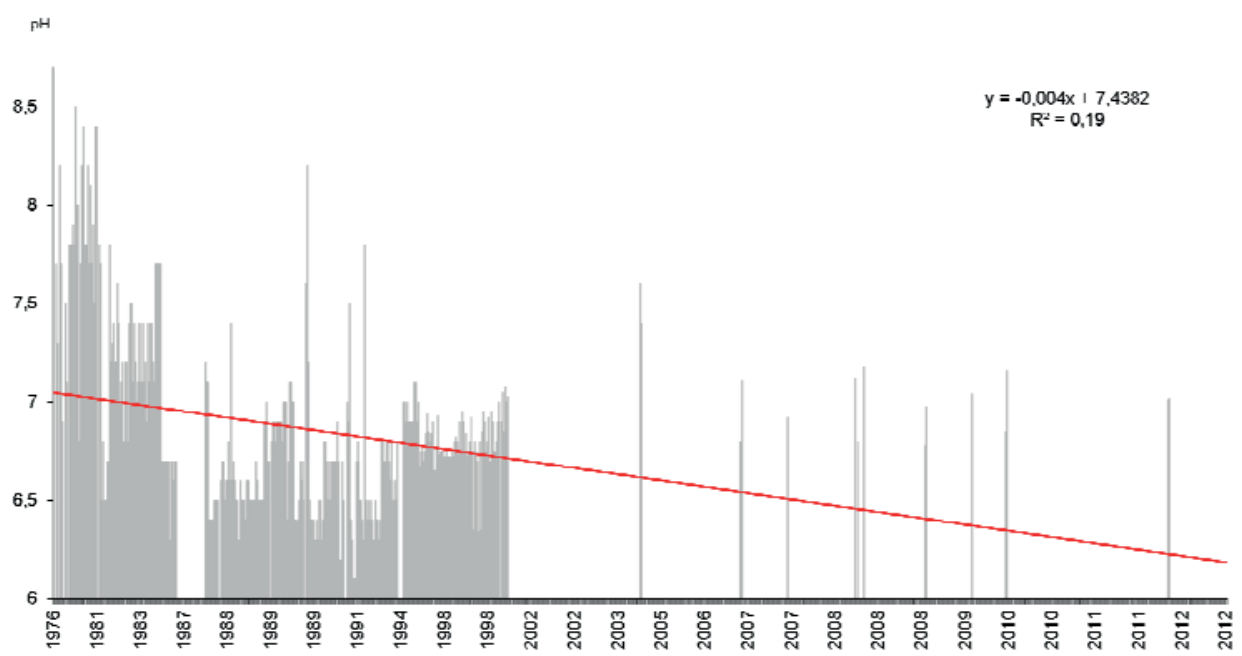

Pис. 4. Изменение величины рН в подземных водах за время эксплуатаиии водозабора

Fig. 4. Change of $p H$ value in underground waters during water intake operation

(рис. 3) и величиной водородного показателя $\mathrm{pH}$ (рис. 4). Обобщенные данные по всем скважинам водозабора показывают, что с уменьшением величины водородного показателя рН за счет подкисления подземных вод эксплуатационного водоносного горизонта фильтрационным потоком перетекания сверху наблюдается рост концентрации ионов железа.

Выявленная тенденция в поведении концентрации железа может объясняться тем, что при формировании депрессионной воронки в процессе эксплуатации водозабора возникает и сохраняется во времени своеобразный геохимический барьер за счет подтягивания кислых подземных вод из поверхностного водоносного горизонта, химический состав которого формируется под выраженным влиянием болотных вод с низким значением водородного показателя $\mathrm{pH}$. Таким образом формиру- ются благоприятные условия для роста концентрации ионов железа в растворенной форме. В условиях работы водозабора доля кислых болотных вод, имеющих весьма широкое распространение в районе водозаборного участка (рис. 1), поддается количественной оценке, которая может быть получена с использованием численного моделирования.

Анализ химического состава по отдельным водозаборным скважинам показывает, что выявленная тенденция в поведении концентрации железа изменяется по площади водозаборного участка. Скорее всего это может быть связано с неоднородностью геологического разреза и формированием сложного характера процессов вертикального перетекания за счет литологических окон в раздельных толщах или, наоборот, увеличения мощности водоупоров на отдельных локальных участках. 


\section{Гидродинамическое моделирование работы водозабора}

Выявленные по результатам режимных наблюдений закономерности изменений химического состава подземных вод позволяют с большой долей вероятности предположить наличие тесной связи между гидрогеохимическим режимом подземных вод и интенсивностью эксплуатации месторождения. Для количественной оценки этой связи нами предпринята попытка исследовать гидрогеологические условия эксплуатации подземных вод с использованием гидродинамического моделирования. Главной задачей при этом является вопрос количественной оценки вероятного процесса смешения подземных вод, поступающих из приповерхностных частей гидрогеологического разреза на глубину заложения фильтров эксплуатационных скважин. С точки зрения оценки качества подземных вод процессы смешения могут иметь решающее значение. Подземные воды в приповерхностных условиях насыщены органическими соединениями, имеют кислую реакцию среды и за счёт этого способны влиять на устойчивость органоминеральных комплексных соединений железа, удерживая его ионы в растворе. Такое техногенное изменение геохимической обстановки может существенно ухудшить әффективность мероприятий по снижению концентрации (растворенных форм) железа в технологическом процессе водоподготовки.

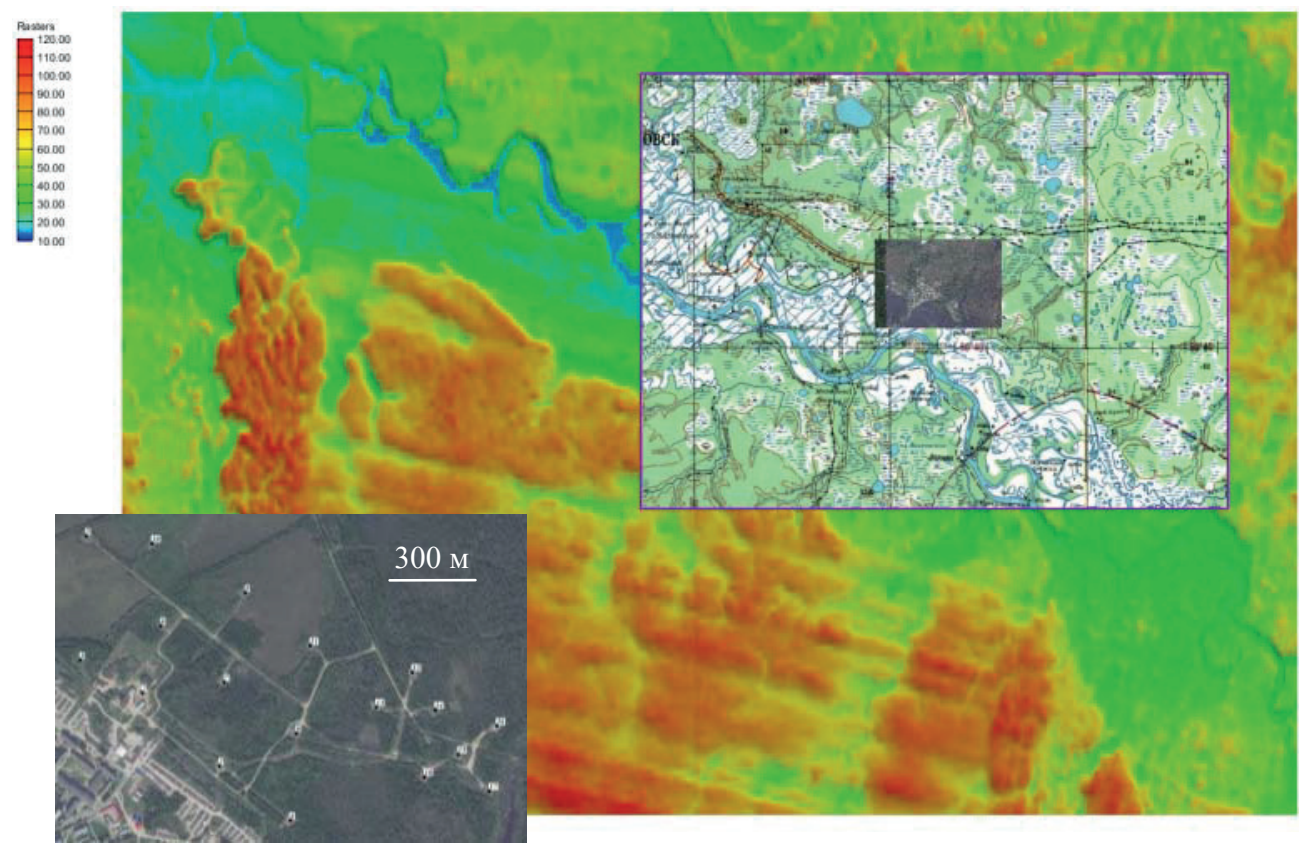

Рис. 5. Совмещенные слои топографической основы, иифровой модели рельефа, грании конечно-разностной сетки численной модели области фильтращии (синий контур) и кослоснимка, использованного для привязки водозаборных скважин (врезка)

Fig. 5. Combined layers of topographical basis, digital relief model, borders of a finite-difference grid of numerical model of filtration area (blue contour) and the satellite image used for binding water wells (insert)

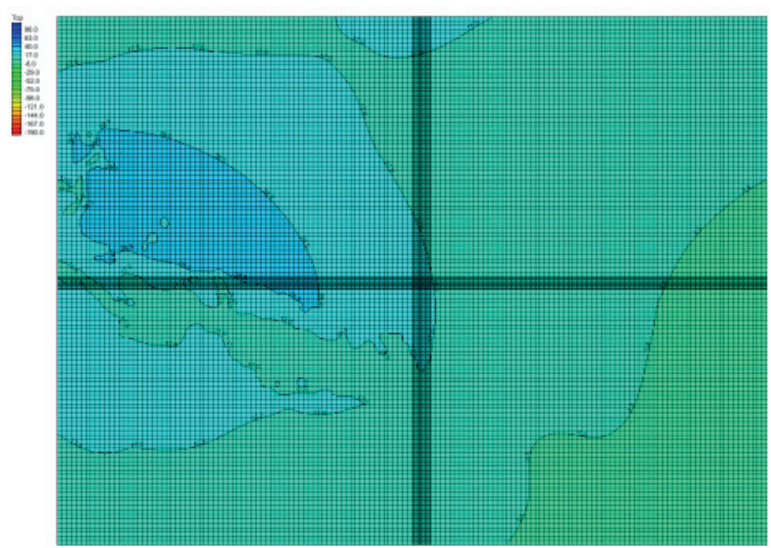

$a / a$

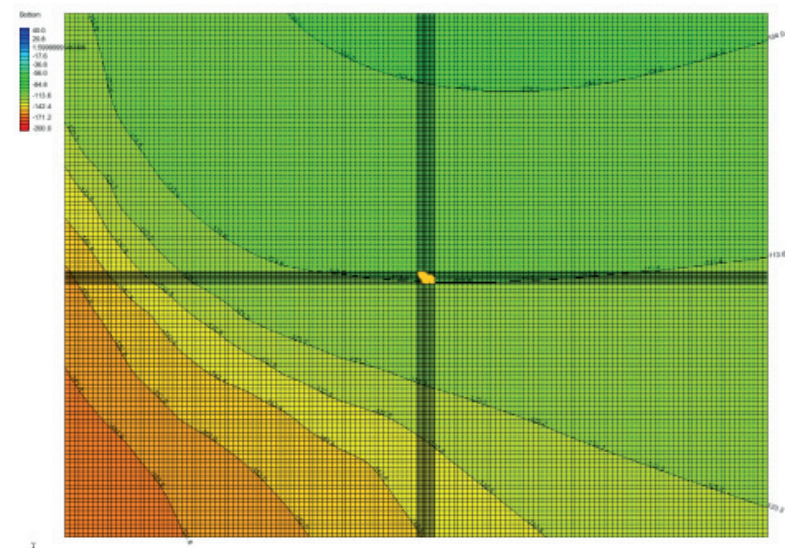

$\sigma / b$

Pис. 6. Абсолютные отметки кровли (а) и подошвы (б) толщи новомихайловской и атлылской свит

Fig. 6. Absolute marks of a roof (a) and sole (b) of thickness of Novomikhaylovsky and Atlymsky suites 
Условия применения гидродинамического моделирования сильно ограничены дефицитом имеющейся гидрогеологической информации для полноценной модели водозабора, но позволяют дать обобщенную оценку изменения гидрогеологических условий под влиянием эксплуатации на основе водного баланса. В такой постановке гидрогеологические условия воспроизводятся в обобщенном виде, где ведущим фактором искусственного воздействия выступает суммарный водоотбор с условно равномерным распределением нагрузки на эксплуатационные скважины.

Водовмещающая толща представлена породами, имеющими слоистое строение с выделением водоносных комплексов четвертичного и палеогенового возраста. Работа эксплуатационных скважин задана в фиктивном слое в средней части водоносного горизонта палеогеновых отложений мощностью 15 м, отвечающей длине фильтров. Размеры области фильтрации $(160 \times 120$ км) выбирались с таким расчётом, чтобы возмущение от работы водозабора не достигало внешних контуров модели. Кровля верхнего слоя соответствует цифровой модели рельефа SRTM30 (рис. 5). Отметки подошвы основной эксплуатационной толщи отложений новомихайловской и атлымской свит совпадают с отметками кровли тавдинской свиты, импортированными из соответствующего покрытия электронной геологической карты масштаба 1:1000000. Из этого же источника получены данные о суммарной мощности отложений новомихайловской и атлымской свит, которые были пересчитаны в абсолютные отметки их кровли (рис. 6). В результате схематизации гидрогеологических условий получена шестислойная численная модель области фильтрации (рис. 7).

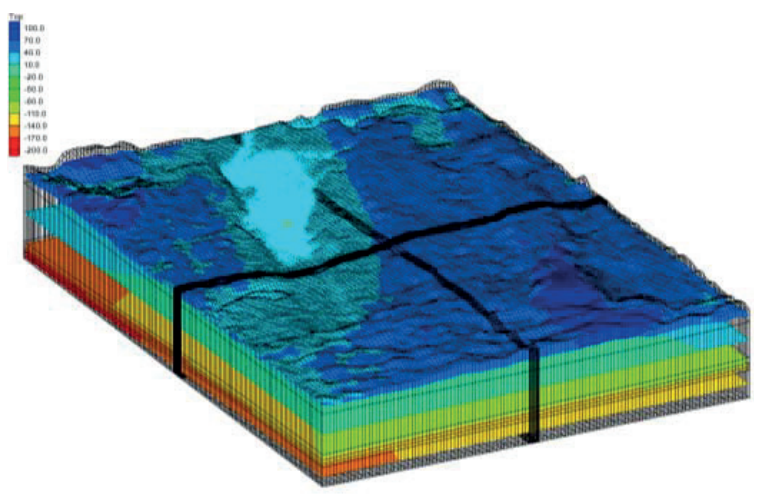

Pис.7. Конечно-разностная сетка численной модели области фильтрации (сетка имеет более плотную разбивку в гра ницах водозаборного участка, вертикальный масштаб для наглядности увеличен)

Fig. 7. Finite-difference grid of numerical model of filtration area (the grid has more dense breakdown in borders of the water intaking site, the vertical scale is increased for illustrative purposes)

Моделирование выполнялось поэтапно с последовательным усложнением строения модели. Адекватность модели оценивалась упрощенно по вели- чинам понижений в расчётных блоках с нагрузкой. В качестве критерия точности модели принималась близость расчетных понижений к измеренным уровням в эксплуатационных скважинах. Предварительные численные эксперименты показали необходимость учёта на модели питающих границ.

На первом этапе граничные условия были представлены только поверхностными водами р. Оби и площадным инфильтрационным питанием, поступающим в первый (верхний) слой модели с интенсивностью, заданной пропорционально величине атмосферных осадков.

Результаты моделирования показывают (рис. 8), что возмущение от эксплуатационных скважин резко ограничивается по площади влиянием русла р. Оби, но распространяется на большое расстояние вверх по направлению естественного фильтрационного потока.

С точки зрения схематизации гидрогеологических условий такой вариант модели требует уточнения, поскольку иные поверхностные водные объекты (многочисленные озера и болотные массивы) по характеру гидравлической связи с приповерхностными водоносными горизонтами не отличаются от главной реки, реализованной в виде внутренних граничных условий области фильтрации.

Уточненный вариант численной модели дополнительно учитывает наличие крупных болотных массивов (рис. 9).

На модели воспроизведена работа водозабора в стационарном режиме фильтрации с максимальной производительностью (32000 м³ $/$ сут). Результаты в виде структуры фильтрационных потоков на фоне топографической карты показаны на рис. 10. Характерные размеры линий тока приведены в табл. 1.

Расчеты показывают, что предельный размер зоны захвата потока (площади депрессионной воронки) существенно ограничивается при комплексном влиянии всех видов питающих границ первого слоя численной модели.

Таблица 1. Параметры линий тока в границах области захвата при наличии интенсивного инфильтрационного питания

Table 1. Parameters of streamlines in borders of capture region in the presence of intensive infiltration delivery

\begin{tabular}{|c|c|c|c|c|}
\hline $\begin{array}{c}\text { Показатель } \\
\text { Indicator }\end{array}$ & $\begin{array}{c}\text { Длина, м } \\
\text { Length, m }\end{array}$ & $\begin{array}{c}\text { Время, сут } \\
\text { Time, days }\end{array}$ & $\begin{array}{c}\text { Время, год } \\
\text { Time, year }\end{array}$ & $\begin{array}{c}\text { Скорость, м/сут } \\
\text { Speed, m/days }\end{array}$ \\
\hline $\begin{array}{c}\text { мин. } \\
\text { тіn. }\end{array}$ & 5067,19 & 86788,5 & 237,78 & 0,058 \\
\hline $\begin{array}{c}\text { макс. } \\
\text { max. }\end{array}$ & 44213 & 12658000 & 34679,45 & 0,003 \\
\hline $\begin{array}{c}\text { среднее } \\
\text { mean }\end{array}$ & 13160,2 & 872251 & 2389,73 & 0,015 \\
\hline
\end{tabular}

Темпы продвижения подземных вод по эксплуатационному водоносному комплексу по направлению к скважинам неравномерны, изменяются в соответствии с переменной величиной гидравличе- 

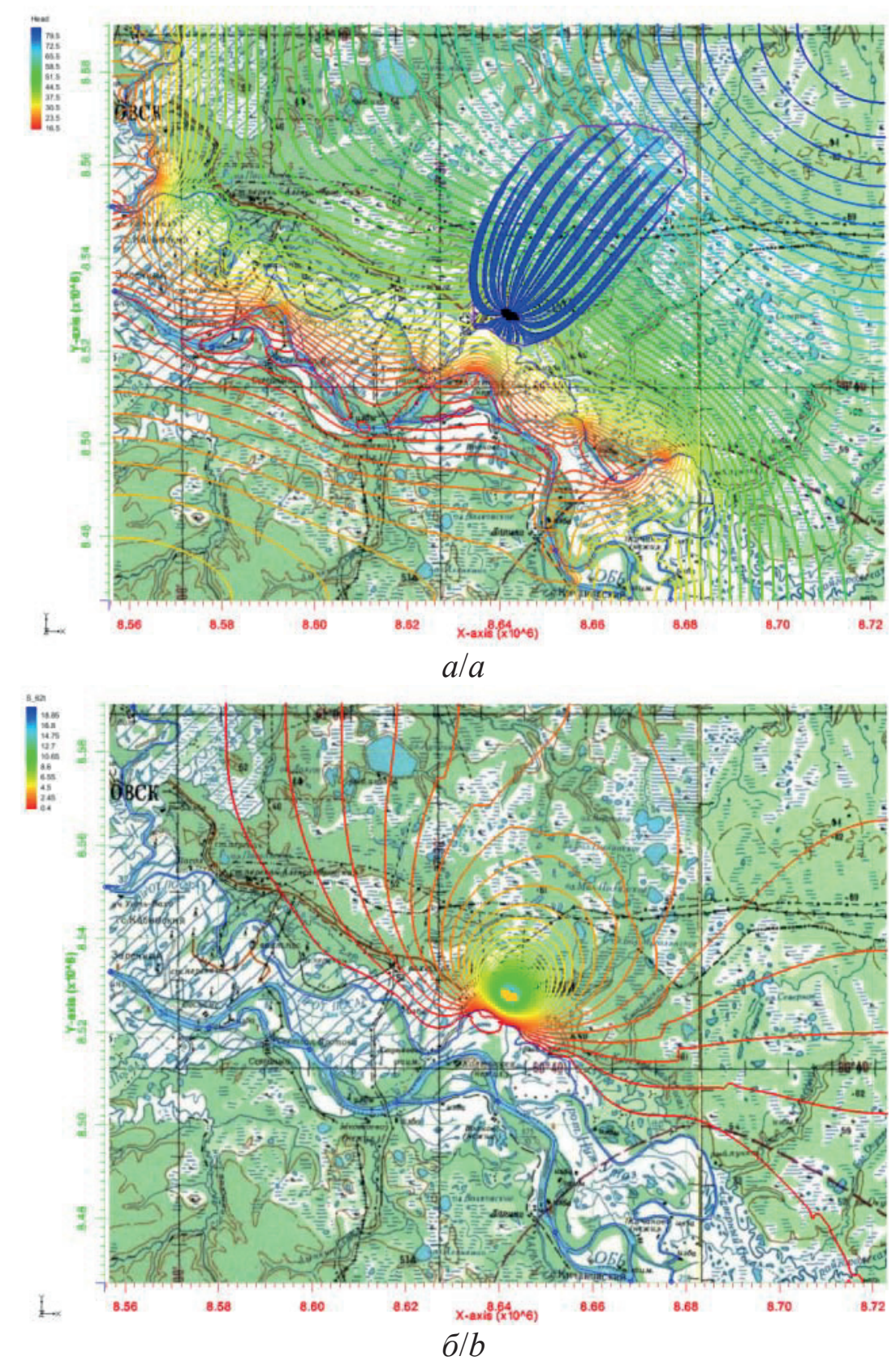

Рис. 8. Расчётное поле напоров ( а ) и понижения уровня (б) в третьем слое модели (с фильтрами водозаборных скважин) и предельный размер зоны захвата фильтраиионного потока эксплуатаиионныли скважинами

Fig. 8. Estimated position of pressures ( $a$ ) and lowering of the level (b) in the third layer of the model (with filters of water wells) and the extreme size of capture region of a filtrational stream by operational wells

ского уклона и могут быть показаны на схеме линий тока, построенной с использованием возможностей модуля MODPATH (рис. 11).

Для расчётного срока работы водозабора в течение 10000 сут предельные размеры зоны захвата фильтрационного потока практически не выходят за границы водозаборного участка (рис. 12, табл. 2). Однако юго-западная часть 3-го пояса 30ны санитарной охраны водозабора захватывает часть городской застройки, где сосредоточены гаражные комплексы.
Таблица 2. Параметры линий тока в границах области захва та на расчетный срок 10000 сут при суммарной производительности $32000 \mathrm{~m}^{3} /$ сут.

Table 2. $\quad$ Parameters of streamlines in borders of capture region for the target time limit of 10000 days at total capacity of $32000 \mathrm{~m}^{3} / \mathrm{d}$

\begin{tabular}{|c|c|c|c|c|}
\hline $\begin{array}{c}\text { Показатель } \\
\text { Indicator }\end{array}$ & $\begin{array}{c}\text { Длина, } \mathrm{m} \\
\text { Length, } \mathrm{m}\end{array}$ & $\begin{array}{c}\text { Bремя, сут } \\
\text { Time, days }\end{array}$ & $\begin{array}{c}\text { Bремя, год } \\
\text { Time, year }\end{array}$ & $\begin{array}{c}\text { Скорость, м/сут } \\
\text { Speed, } \mathrm{m} / \text { days }\end{array}$ \\
\hline мин./min. & 156,00 & 10000 & 27,4 & 0,016 \\
\hline макс./max. & 935,55 & 10000 & 27,4 & 0,094 \\
\hline среднее/mean & 755,73 & 10000 & 27,4 & 0,076 \\
\hline
\end{tabular}




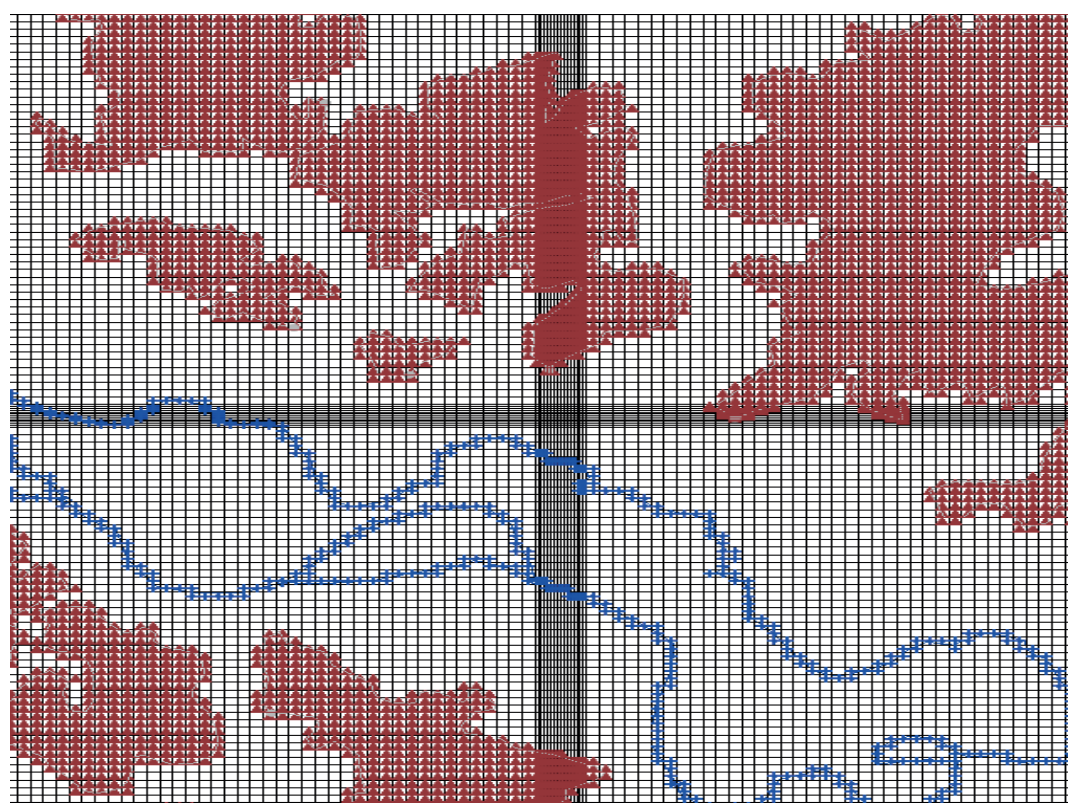

Pис. 9. Граничные условия, заданные в верхнем слое модели (линейные - реки, площадные - крупные болотные массивы)

Fig. 9. Boundary conditions, set in the high layer of model (linear - the rivers, vulgar - large marsh massifs)

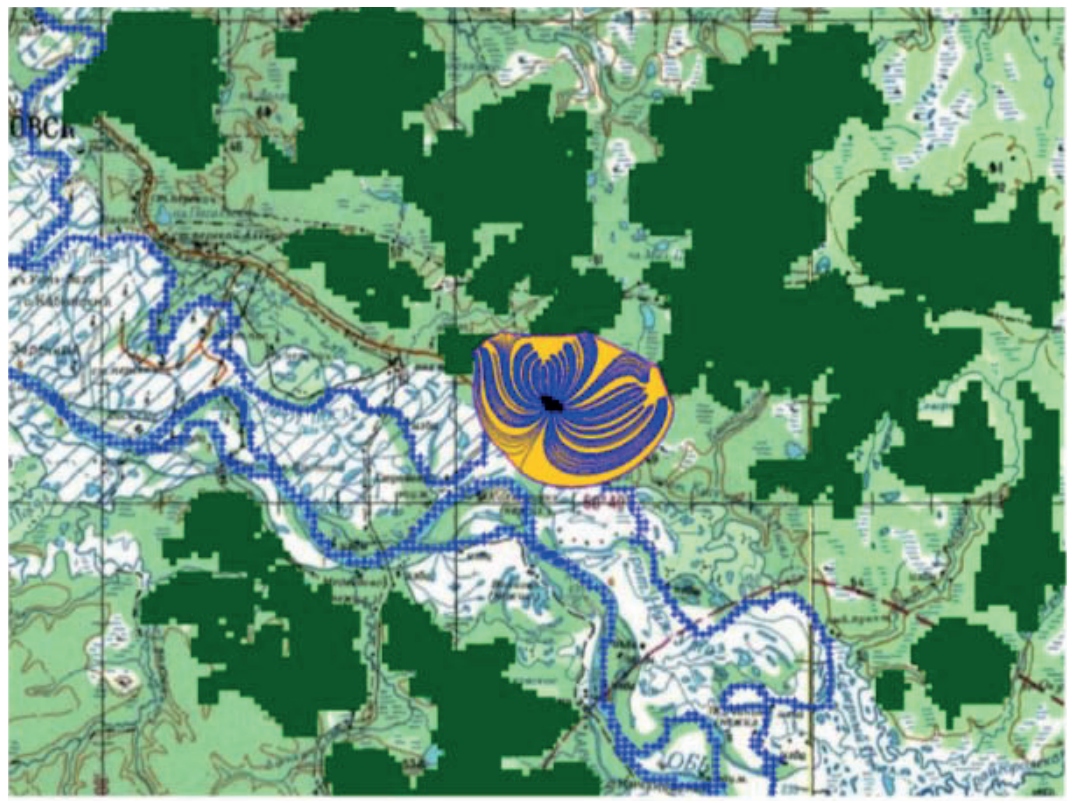

Рис. 10. Предельные размеры зоны захвата фильтрационного потока при наличии интенсивного инфильтрационного питания

Fig. 10. Extreme sizes of capture region of a filtrational stream in the presence of intensive infiltration delivery

Выполненное моделирование позволяет дать оценку балансовых характеристик фильтрационных потоков по трём верхним слоям численной модели, которые приведены в табл. 3. Результаты этих расчётов необходимы для обоснования физикохимических расчётов.

Результаты численного гидродинамического моделирования показывают, что с поверхности во второй слой модели попадает расход подземных вод в количестве $2929,4 \mathrm{~m}^{3} /$ сут, близких по геохимическому облику к поверхностным водам, фор- мирующимся в значительной степени под влиянием болотных массивов.

С учетом суммарного расхода водозабора интенсивностью $32000 \mathrm{~m}^{3} /$ сут доля поверхностных вод может достигать $9 \%$.

Опыт эксплуатации водозабора показывает, что его реальная производительность значительно меньше объёмов утвержденных запасов подземных вод (32000 м 3 /сут). Она неравномерно изменялась за время работы водозабора (рис. 13), достигая максимума в 1996 г. при дебите $12340 \mathrm{~m}^{3}$ /сут. 


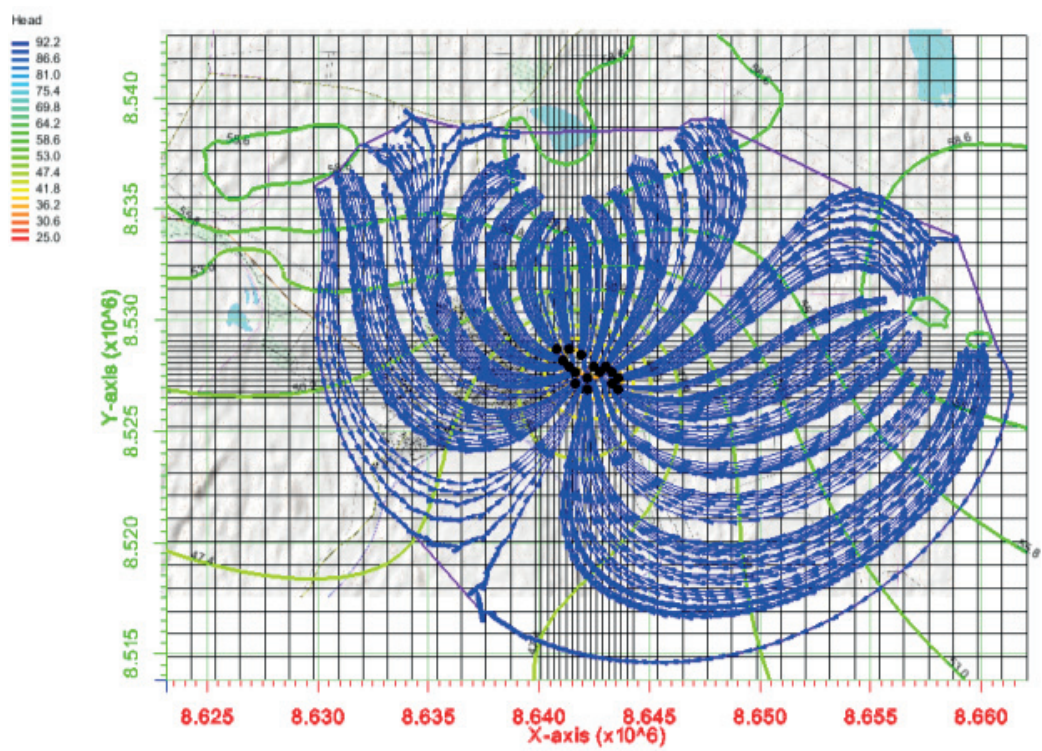

Рис. 11. Темпы движения подземных вод по направлению к водозаборным скважинам (расстояние между стрелками соответствует времени 100000 сут или 273 года)

Fig. 11. Rates of underground water movement towards water wells (the distance between arrows corresponds to 100000 days or 273 years)

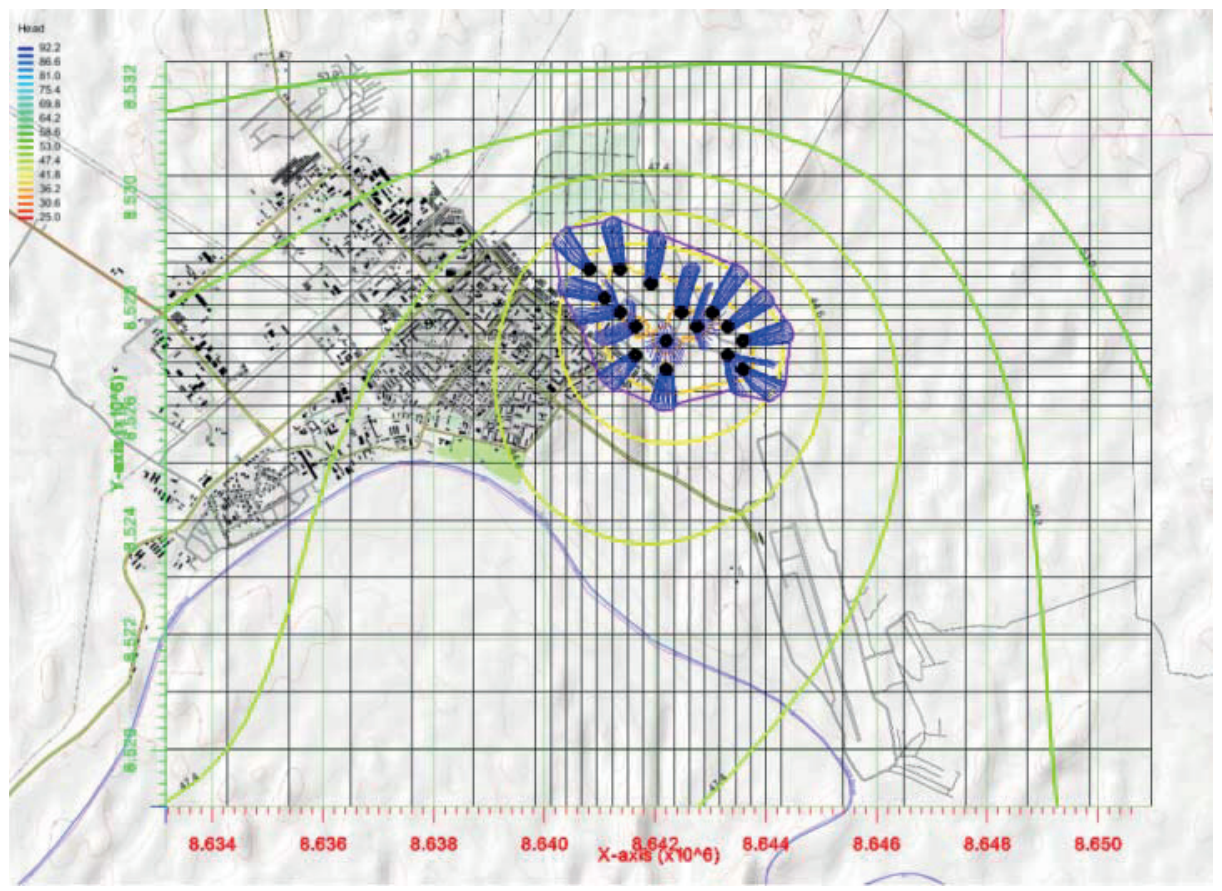

Рис.12. Размеры зоны захвата фильтрационного потока на расчётный срок 10000 сут при суммарной производительности $32000 \mathrm{~m}^{3} /$ cym.

Fig. 12. Sizes of filtrational stream capture zone for the rated term of 10000 days at total capacity of $32000 \mathrm{~m}^{3} / \mathrm{d}$

На сегодняшний день суммарная производительность эксплуатационных скважин находится на уровне $5100 \mathrm{~m}^{3} /$ сут. В этих условиях нами выполнена прогнозная оценка работы водозабора при существующей интенсивности водоотбора.

Результаты моделирования показывают, что при расходе водозабора $5120 \mathrm{~m}^{3} /$ сут существенно сокращается предельная область захвата фильтрационного потока (рис. 14).
Более наглядно это сокращение проявляется для зоны захвата фильтрационного потока на расчетный срок 10000 сут, которая практически не выходит за границы площади расположения водозаборных скважин. (рис. 15, табл. 4).

Результаты численного гидродинамического моделирования по второму варианту эксплуатационной нагрузки, представленные балансовыми характеристиками фильтрационного потока, показаны в табл. 5 . 


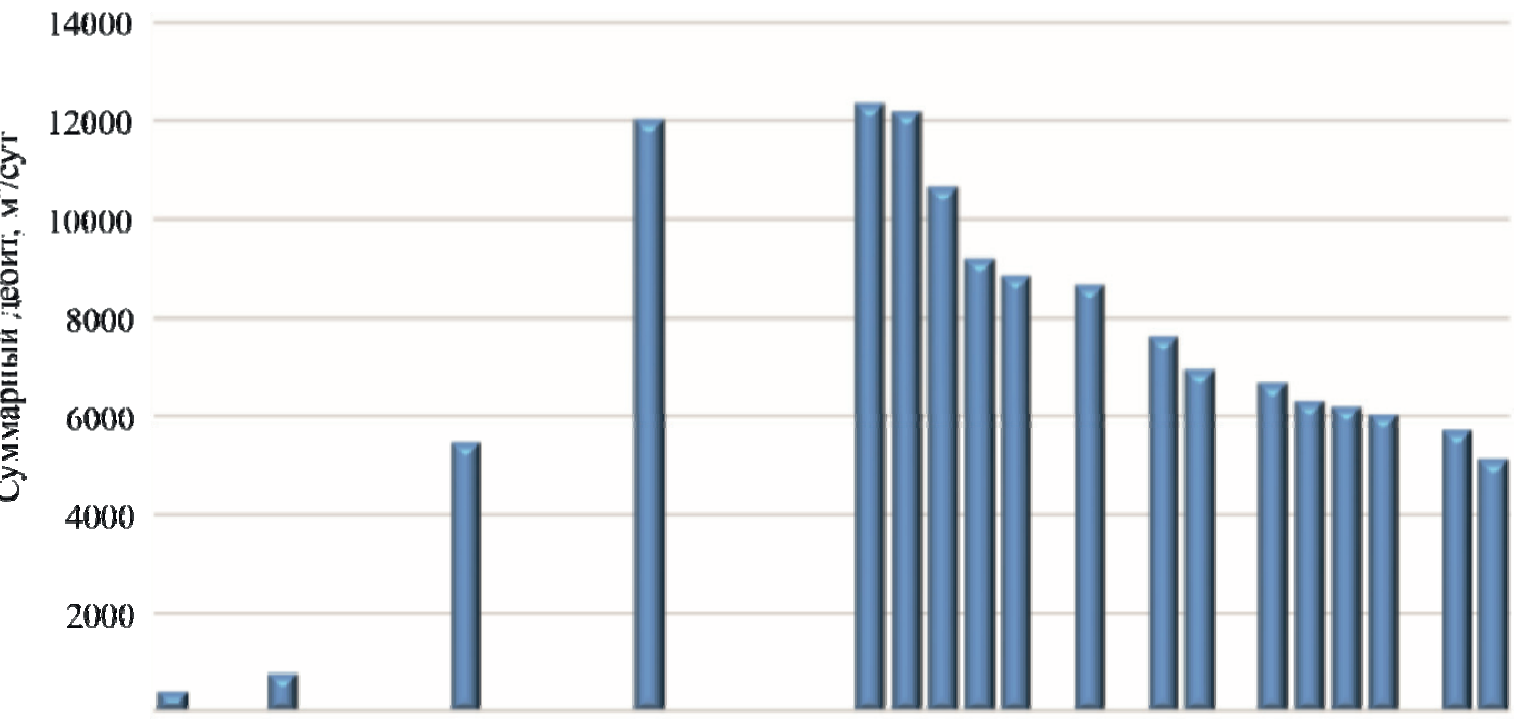

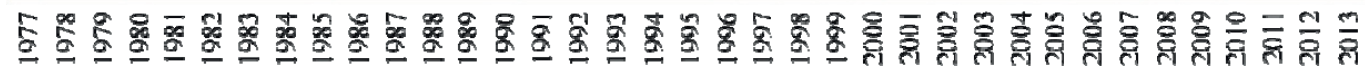
Время работн

Рис. 13. Изменение производительности водозабора за время эксплуатации

Fig. 13. Change in efficiency of a water intake during operation

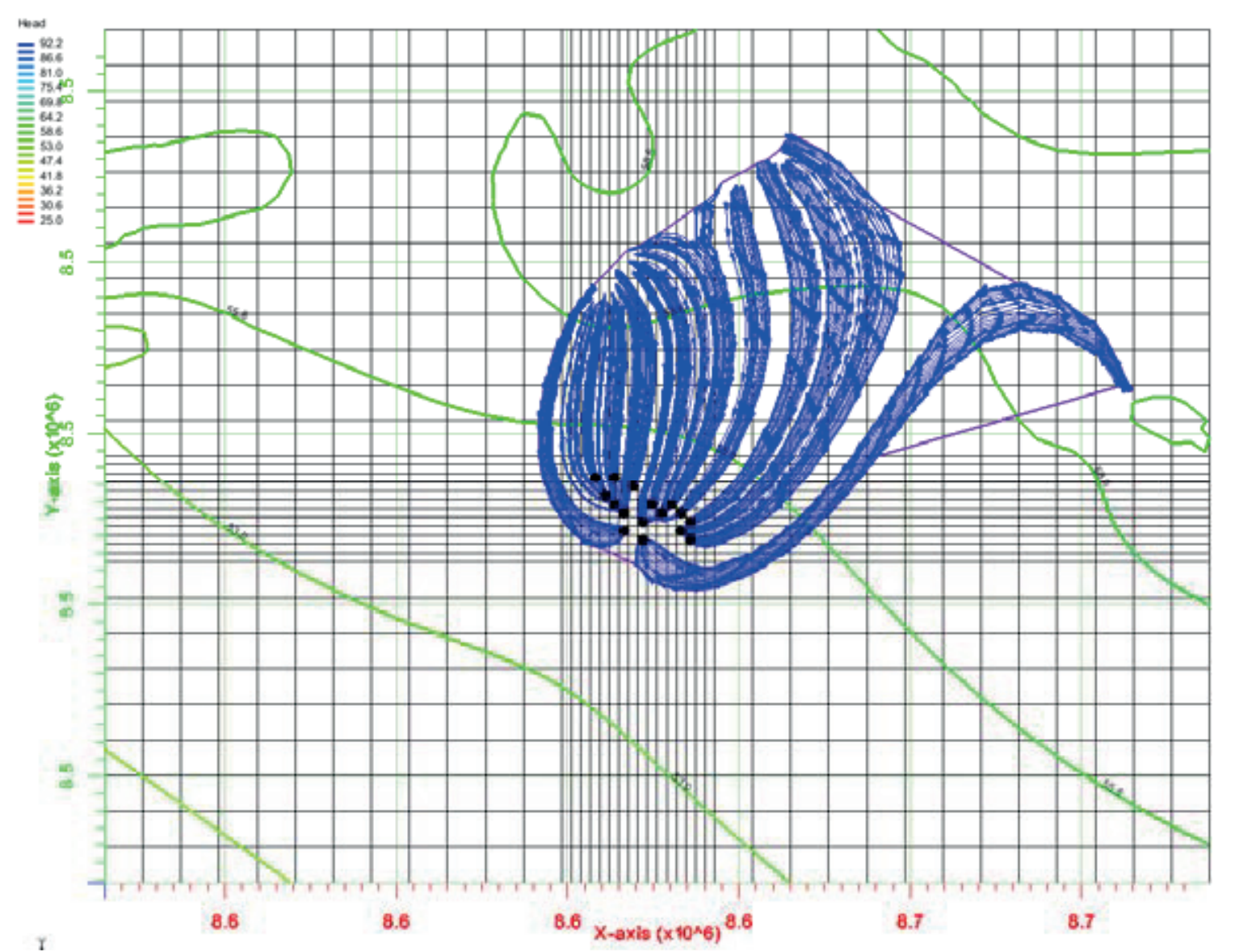

Pис. 14. Предельные размеры зоны захвата фильтрационного потока и темпы движения подземных вод по направлению к водозаборным скважинам (расстояние между стрелками соответствует времени 100000 сут или 274 года) при уменьшении производительности водозабора до $5120 \mathrm{~m}^{3} /$ сут

Fig. 14. Extreme sizes of capture region of a filtrational stream and rates of underground water movement towards water wells (the distance between arrows corresponds to 100000 days or 274 years) at decrease of efficiency of water intake up to $5120 \mathrm{~m}^{3} / \mathrm{d}$ 
Таблица 3. Балансовые характеристики выделенного участка по трёл верхнил слоям модели при сумларной произ водительности водозабора $32000 \mathrm{~m}^{3}$ ссут (фильтрь эксплуатационных скважин расположены в 3-л слое)

Table 3. $\quad$ Balance characteristics of the allocated site on three high layers of model at total capacity of a water intake of $32000 \mathrm{~m}^{3} / d$ (filters of operational wells are located in the $3^{\text {rd }}$ layer)

\begin{tabular}{|c|c|c|c|c|c|c|}
\hline Направле- & \multicolumn{6}{|c|}{ слой/layer } \\
\cline { 2 - 7 } $\begin{array}{c}\text { ние приток } \\
\text { Inflow } \\
\text { direction }\end{array}$ & $\begin{array}{c}\text { приход } \\
\text { income }\end{array}$ & $\begin{array}{c}\text { расход } \\
\text { charge }\end{array}$ & $\begin{array}{c}\text { приход } \\
\text { income }\end{array}$ & $\begin{array}{c}\text { pacход } \\
\text { charge }\end{array}$ & $\begin{array}{c}\text { приход } \\
\text { income }\end{array}$ & $\begin{array}{c}\text { расход } \\
\text { charge }\end{array}$ \\
\hline $\begin{array}{c}\text { справа } \\
\text { on the right }\end{array}$ & 661,9 & 0 & 6025,9 & 0 & 793,0 & 0 \\
\hline $\begin{array}{c}\text { спереди } \\
\text { in front }\end{array}$ & 155,2 & $-0,8$ & 2562,1 & $-19,1$ & 326,2 & $-2,4$ \\
\hline $\begin{array}{c}\text { снизу } \\
\text { from below }\end{array}$ & 94,6 & $-2929,4$ & 66,1 & $-28334,9$ & 445,6 & $-14,4$ \\
\hline $\begin{array}{c}\text { слева } \\
\text { at the left }\end{array}$ & 189,9 & 0 & 2882,6 & 0 & 362,0 & 0 \\
\hline $\begin{array}{c}\text { сверху } \\
\text { from above }\end{array}$ & 0 & 0 & 2929,4 & $-94,6$ & 28334,89 & $-66,1$ \\
\hline $\begin{array}{c}\text { сзади } \\
\text { веhind }\end{array}$ & 1828,7 & 0 & 13982,8 & 0 & 1820,7 & 0 \\
\hline
\end{tabular}

Таблица 4. Паралетры линий тока в границах области захва та на расчетный срок 10000 сут при сумларной про изводительности $5120 \mathrm{~m}^{3} /$ сут

Table 4. $\quad$ Parameters of streamlines in borders of capture region for the target time limit of 10000 days at total capacity of $5120 \mathrm{~m}^{3} / \mathrm{d}$

\begin{tabular}{|c|c|c|c|c|}
\hline $\begin{array}{c}\text { Показатель } \\
\text { Indicator }\end{array}$ & $\begin{array}{c}\text { Длина, м } \\
\text { Length, } \mathrm{m}\end{array}$ & $\begin{array}{c}\text { Время, сут } \\
\text { Time, days }\end{array}$ & $\begin{array}{c}\text { Время, год } \\
\text { Time, уear }\end{array}$ & $\begin{array}{c}\text { Скорость, м/сут } \\
\text { Speed, m/days }\end{array}$ \\
\hline $\begin{array}{c}\text { мин. } \\
\text { min. }\end{array}$ & 80,0463 & 10000 & 27,4 & 0,803 \\
\hline $\begin{array}{c}\text { макс. } \\
\text { тах. }\end{array}$ & 244,557 & 10000 & 27,4 & 2,446 \\
\hline $\begin{array}{c}\text { среднее } \\
\text { mean }\end{array}$ & 162,92 & 10000 & 27,4 & 1,629 \\
\hline
\end{tabular}

Таблица 5. Балансовые характеристики выделенного участка по трёл верхнил слоям модели при сулмарной произ водительности водозабора $5120 \mathrm{~m}^{3} /$ сут (в 3-ем слое работают скважины)

Table 5. Balance characteristics of the allocated site on three high layers of the model at total capacity of water intake of $5120 \mathrm{~m}^{3} / d$ (the wells work in the $3^{\text {rd }}$ layer)

\begin{tabular}{|c|c|c|c|c|c|c|}
\hline Направле- & \multicolumn{6}{|c|}{ слой/layer } \\
\cline { 2 - 7 } $\begin{array}{c}\text { ние притока } \\
\text { Inflow } \\
\text { direction }\end{array}$ & $\begin{array}{c}\text { приход } \\
\text { income }\end{array}$ & $\begin{array}{c}\text { расход } \\
\text { charge }\end{array}$ & $\begin{array}{c}\text { приход } \\
\text { income }\end{array}$ & $\begin{array}{c}\text { расход } \\
\text { charge }\end{array}$ & $\begin{array}{c}\text { приход } \\
\text { іnсоте }\end{array}$ & $\begin{array}{c}\text { расход } \\
\text { charge }\end{array}$ \\
\hline $\begin{array}{c}\text { справа } \\
\text { on the right }\end{array}$ & 175,19 & 0 & 1604,86 & 0 & 204,46 & 0 \\
\hline $\begin{array}{c}\text { спереди } \\
\text { in front }\end{array}$ & 0 & $-105,24$ & 0 & $-1766,04$ & 0 & $-224,39$ \\
\hline $\begin{array}{c}\text { снизу from } \\
\text { веlow }\end{array}$ & 1,37 & $-661,36$ & 12,20 & $-4551,53$ & 70,28 & $-1,52$ \\
\hline $\begin{array}{c}\text { слева } \\
\text { at the left }\end{array}$ & 0 & $-75,92$ & 0 & $-1016,30$ & 0 & $-111,27$ \\
\hline $\begin{array}{c}\text { сверху } \\
\text { from above }\end{array}$ & 0 & 0 & 661,36 & $-1,37$ & 4544,04 & $-12,20$ \\
\hline $\begin{array}{c}\text { сзади } \\
\text { behind }\end{array}$ & 665,96 & 0 & 5056,62 & 0 & 650,76 & 0 \\
\hline
\end{tabular}

Анализ межпластовых перетеканий по данным моделирования позволяет сделать вывод о том, что при уменьшении производительности водозабора с поверхности во второй слой модели попадает расход в количестве $661,36 \mathrm{~m}^{3} /$ сут, близкий по геохимическому облику к поверхностным водам, формирующимся в значительной степени под влиянием болотных массивов. В этом случае с учетом суммарного расхода водозабора интенсивностью $5120 \mathrm{~m}^{3} /$ сут доля поверхностных вод на глубине установки фильтров эксплуатационных скважин возрастает до $12,92 \%$, т. е. составляет почти $13 \%$. Результаты моделирования показывают, что при изменении производительности водозабора доля поверхностных вод, поступающих на глубину, изменяется несущественно и может быть принята для проведения прогнозных физико-химических расчётов состава природных растворов на уровне $10 \%$ от суммарного расхода эксплуатационных скважин.

\section{Выводы}

На основе анализа техногенных изменений гидрогеологических условий с применением численного моделирования установлено:

1. Ведущим фактором формирования эксплуатационных запасов подземных вод является возможность их восполнения за счет емкостных запасов эксплуатационного водоносного комплекса палеогеновых отложений и привлекаемых ресурсов неоген-четвертичного водоносного комплекса, которые составляют подчиненную, но значительную часть в суммарном водоотборе эксплуатационных скважин.

2. В свою очередь запасы подземных вод неогенчетвертичного водоносного комплекса пополняются избыточным (по сравнению с величиной испарения) количеством атмосферных осадков и обеспечены влиянием питающих границ (первого рода), представленных многочисленными (и обширными по площади) болотными массивами и другими поверхностными водоемами и водотоками.

3. Обширные болотные массивы способствуют формированию восстановительной геохимической обстановки водной среды, которая под влиянием разницы напоров за счет создания депрессии в эксплуатационном водоносном комплексе способна оказывать влияние на изменение условий водной среды в нижних частях гидрогеологического разреза в зоне работы фильтров водозаборных скважин.

4. Объемы перетекания, формирующиеся под влиянием работы группового водозабора, непостоянны во времени в связи с выявленными тенденциями изменения водопотребления. Количественная оценка объемов перетекания и их изменения во времени поддается количественному учету с использованием численного моделирования. 


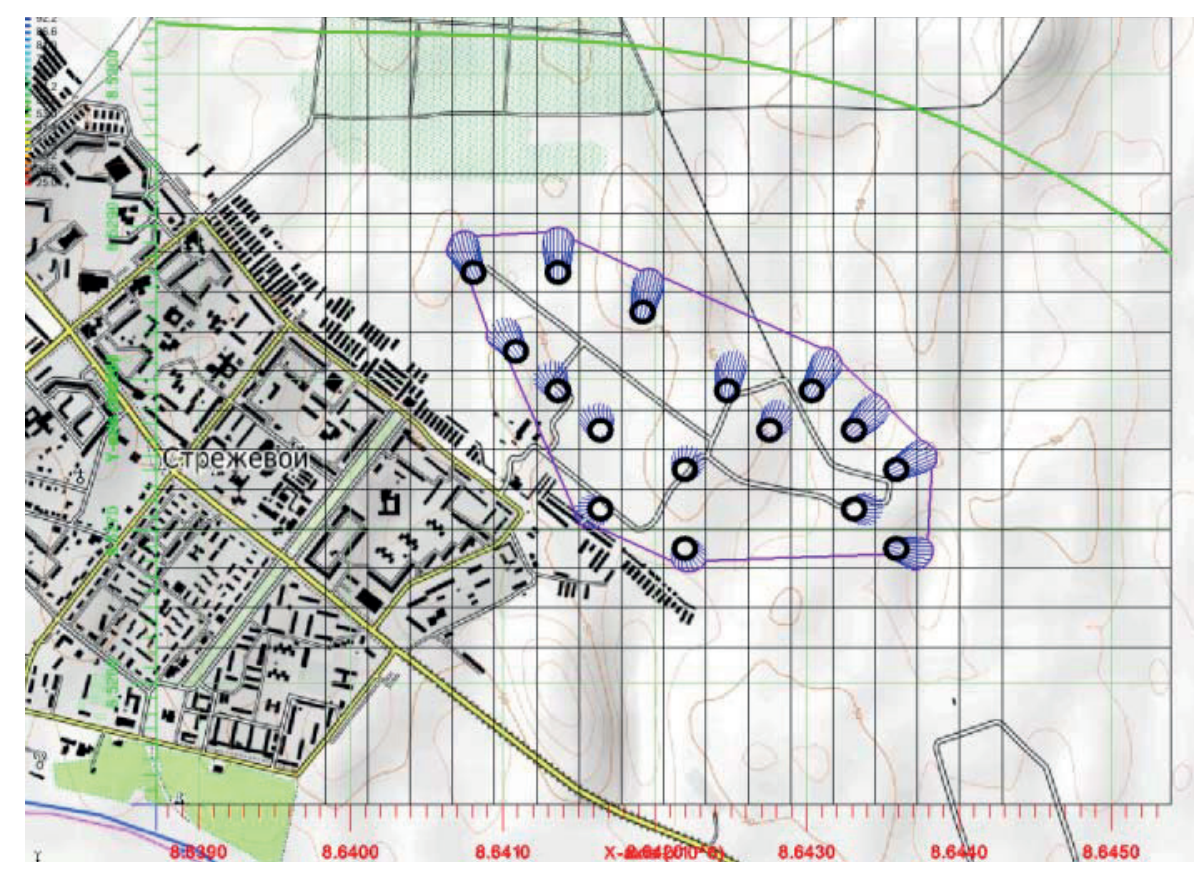

Рис. 15. Размеры зоны захвата фильтрационного потока на расчётный срок 10000 сут при сумларной производительности $5120 \mathrm{~m}^{3} /$ cym.

Fig. 15. Sizes of filtrational stream capture region for the target time limit of 10000 days at total capacity of $5120 \mathrm{~m}^{3} / \mathrm{d}$

5. Полученные оценки изменения водного баланса в процессе эксплуатации позволяют утверждать, что доля привлекаемых ресурсов подземных вод из верхней гидродинамической зоны неоген-четвертичного водоносного комплекса составляет значительную долю и изменяется в процентном отношении от 9 до $13 \%$.

6. На региональной упрощенной численной модели района водозабора получена оценка пространственных размеров области возмущения под влиянием действующего водозабора.

7. Численная модель показывает, что границы области влияния эксплуатационных скважин при максимальном водоотборе не превышают 50 км. Поэтому локальная численная модель водозабора может быть ограничена размерами $25 \times 25$ кM.

8. Режим эксплуатации водозабора оказывает существенное влияние на состав подземных вод на входе технологической цепочки обработки воды перед подачей потребителю, и должен учитываться при выборе оптимального режима работы очистных сооружений (частота включе-

\section{СПИСОК ЛИТЕРАТУРЫ}

1. Гаев А.Я., Савилова Е.Б. Об обеспечении экологической безопасности водозаборов хозяйственно-питьевого назначения нефтедобывающих районов оренбуржья // Вестник Российского университета дружбы народов. Серия: Экология и безопасность жизнедеятельности. - 2017. - Т. 25. - № 2. - С. 294-305.

2. 0 проблеме питьевых вод на урбанизированных территориях А.Я. Гаев, И.Н. Алферов, Ю.А. Килин, И.В. Куделина // Эко- ния фильтров в режим промывки, частота замены фильтрующего материала).

Заметим, что проект очистных сооружений является неотъемлемой частью подсчета запасов подземных вод и разрабатывается по исходному химическому составу, полученному на стадии разведочных работ, т. е. как правило до начала работы водозабора. Результаты выполненного исследования показывают, что без физико-химического прогноза эволюции гидрогеохимической обстановки эксплуатационного водоносного комплекса, опирающегося на результаты гидродинамического моделирования, невозможно полноценно учесть особенности изменения химического состава подземных вод в процессе перспективной работы водозабора.

Важно отметить, что результаты комплексного моделирования гидрогеологических условий позволяют на стадии разработки проекта водозабора внести дополнительные существенные уточнения в технологическую схему водоподготовки с целью повышения ее эффективности ее эксплуатационных характеристик.

логические проблемы промышленных городов. Сборник научных трудов по материалам 7-й Всероссийской научно-практической конференции с международным участием. - Саратов, 2015. - С. 259-263.

3. Гидрогеоэкологические условия водоснабжения населения юга Сибирского региона / Д.С. Покровский, Е.М. Дутова, А.А. Балобаненко, В.Д. Покровский, А.Ф. Рехтин // Вестник Томского государственного университета. - 2014. - № 384. C. 189-197. 
4. Проблемы воды, здоровья и безопасности оренбуржщев в перспективе / А.Я. Гаев, И.В. Куделина, Т.В. Леонтьева, И.Н. Алферов, Е.Б. Савилова // Вестник Волжского университета им. В.Н. Татищева. - 2013. - Т. 1. - № 4 (14). - С. 20-24.

5. Крайнов С.Р., Рыженко Б.Н., Швец В.М. Геохимия подземных вод. - М.: Центр. ЛИТНефтеГаз, 2012. - 672 с.

6. Крайнов С.Р., Швец В.М. Геохимия подземных вод хозяйственно-питьевого назначения. - М.: Недра, 1987. - 237 с.

7. Фи Т.Х., Строкова Л.А. Типизация грунтовых толщ территории города Ханой (Вьетнам) при изучении оседания земной поверхности при водопонижении // Известия Томского политехнического университета. Инжиниринг георесурсов. - 2017. T. 328. - № 4. - C. 6-15.

8. Фи Т.Х., Строкова Л.А. Оценка и прогноз оседания земной поверхности в результате извлечения подземных вод в городе Ханой (Вьетнам) // Геоэкология. Инженерная геология, гидрогеология, геокриология. - 2014. - № 2. - С. 169-178.

9. Manganese release linked to carbonate dissolution during the start-up phase of a subsurface iron removal well in Khabarovsk, Russia / S. Paufler, T. Grischek, J. Feller, J. Herlitzius, V.V. Kulakov // The science of the total environment. - 2019. - V. 650. P. $1722-1733$

10. Mi Lin, Asim Biswas, Bennett E.M. Identifying hotspots and representative monitoring area of groundwater changes with time stability analysis // Cience of The Total Environment. - 2019. V. 667. - P. 419-426.

11. Самарцев В.Н., Поздняков С.П. Опыт калибровки геофильтрационной модели берегового водозабора путем совместного использования данных опытно-фильтрационных работ и результатов мониторинга в период эксплуатации // Инженерная геология. - 2017. - № 3. - С. 36-43.

12. Лехов В.А., Поздняков С.П., Бакшевская В.А. Экспериментальное изучение и численное моделирование влияния диффузии на миграцию загрязнения в неоднородных песчано-глинистых отложениях // Инженерная геология. - 2017. - № 5. C. $60-71$.

13. Muhammad Tousif Bhatti, Arif A. Anwar, Muhammad Aslam. Groundwater monitoring and management: Status and options in Pakistan // Computers and Electronics in Agriculture. - 2017. V. 135 . - P. 143-153.

14. Wang P., Pozdniakov S.P., Shestakov V.M Optimum experimental design of a monitoring network for parameter identification at riverbank well fields // Journal of Hydrology. - 2015. V. 523. - P. 531-541.

15. Бочаров В.Л., Савченко О.В. Гидрогеологические условия и оценка экплуат ационных запасов подземных вод бассейна реки Становая Ряса (Липецкая область) // Вестник Воронежского государственного университета. Серия: Геология. - 2015. № 2. - C. 104-108.

16. Shallow groundwater dynamics and its driving forces in extremely arid areas: a case study of the lower heihe river in northwestern CHINA / P. Wang, J. Yu, C. Liu, S.P. Pozdniakov, S.0. Grinevsky // Hydrological Processes. - 2014. - V. 28. - № 3. P. $1539-1553$.

17. Бочаров В.Л., Строгонова Л.Н., Овчинникова Е.С. Проблемы изучения и использования ресурсов подземных питьевых вод Воронежской области // Вестник Воронежского государственного университета. Серия: Геология. - 2010. - № 1. - С. 243-251.

18. Statistical modelling of groundwater contamination monitoring data: a comparison of spatial and spatiotemporal methods / M.I. McLean, L. Evers, A.W. Bowman, M. Bonte, W.R. Jones // Science of The Total Environment. - 2019. - V. 652. P. $1339-1346$.

19. Ayvaz M.T., Elçi A. Identification of the optimum groundwater quality monitoring network using a genetic algorithm based optimization approach // Journal of Hydrology. - 2018. - V. 563. P. 1078-1091.
20. Jamin P., Brouyère S. Monitoring transient groundwater fluxes using the Finite Volume Point Dilution Method // Journal of Contaminant Hydrology. - 2018. - V. 218. - P. 10-18.

21. Accounting for groundwater in future city visions / S.H. Bricker, V.J. Banks, G. Galik, D. Tapete, R. Jones // Land Use Policy. 2017. - V. 69. - P. 618-630.

22. Geochemical groundwater peculiarities of paleogene sediments in the Western Siberia artesian basin / A.A. Balobanenko, V. L'Gotin, E.M. Dutova, A.N. Nikitenkov, I.V. Raduk, D.S. Pokrovsky // IOP Conference Series: Earth and Environmental Science. - 2016.

23. Геохимические особенности подземных вод хозяйственно-питьевого назначения республики Хакасия / Е.М. Дутова, Д.С. Покровский, В.П. Парначев, В.Д. Покровский // Вестник Томского государственного университета. - 2015. - № 394. C. 239-249.

24. Бочаров В.Л., Селезнев К.А. Геохимия стронция в подземных водах в юго-западной краевой части московского артезианского бассейна (Орловская область) // Вестник Воронежского государственного университета. Серия: Геология. - 2012. № 2. - C. 179-189.

25. Kazak E., Pozdniakov S., Muromec N. Field study and iron reactive simulation in riverbank water supply well fields // IAHSAISH Publication GQ10: Groundwater Quality Management in a Rapidly Changing World. Proceedings of the seventh International GroundWater Quality Conference. - Zurich, Switzerland, 2011. - P. 419-422.

26. Лехов А.В., Шваров Ю.В. Рост минерализации эксплуатируемых подземных вод при наличии пирита в покровных отложениях // Геоэкология. Инженерная геология. Гидрогеология. Геокриология. - 2002. - № 4. - С. 316-325.

27. Electric-field enhanced reactivity and migration of iron nanoparticles with implications for groundwater treatment technologies: Proof of concept / M.v Ėerník, J. Nosek, J. Filip, J. Hrabal, D.W. Elliott, R. Zbořil // Water Research. - 2019. - V. 154. P. 361-369.

28. Comparative study of ferrate and thermally activated persulfate treatments for removal of mono- and dichlorobenzenes from groundwater / P. Dobosy, C.É. Vizsolyi, I. Varga, J. Varga, G. Láng, G. Záray // Microchemical Journal. - 2018. - V. 136. - P. 61-66.

29. Sharma S.K., Petrusevski B., Schippers J.C. Biological iron removal from groundwater // AQUA. - 2005. - V. 54. - № 4. P. 239-247.

30. Modeling in situ iron removal from ground water / C.A.J. Appelo, B. Drijver, R. Hekkenberg, M. de Jonge // Ground water. 1999. - V. 37. - № 6. - P. 811-817.

31. Труфанов А.И. Формирование железистых подземных вод. М.: Стройиздат, 1987. - 133 с.

32. Sung W., Morgan J.J. Kinetics and product of ferrous iron oxygenation in aqueous systems // American Chem. Soc. - 1980. V. $14 .-$ P. 561-568.

33. Khushboo Chaudhary, Pankaj Kumar Saraswat, Suphiya Khan. Improvement in fluoride remediation technology using GIS based mapping of fluoride contaminated groundwater and microbe assisted phytoremediation // Ecotoxicology and Environmental Safety. - 2019. - V. 168. - P. 164-176.

34. Sudipta Ghosh (Nath), Anupam Debsarkar, Amit Dutta. Technology alternatives for decontamination of arsenic-rich groundwater - a critical review // Environmental Technology \& Innovation. - 2019. - V. 13. - P. 277-303.

35. Large scale treatment of total petroleum-hydrocarbon contaminated groundwater using bioaugmentation / G. Poi, E. Shahsavari, A. Aburto-Medina, P.Ch. Mok, A.S. Ball // Journal of Environmental Management. - 2018. - V. 214. - P. 157-163.

36. Кулаков В.В. Водоподготовка питьевых вод в водоносном горизонте на тунгусском водозаборе некондиционнных подземных вод в Хабаровске // Водное хозяйство России: проблемы, технологии, управление. - 2016. - № 2. - С. 87-97. 
37. Kazak E., Pozdniakov S., Kazak A. Sensitivity of model of ferrous iron oxidation by dissolved oxygen in the groundwater system // Water-Rock Interaction - Proceedings of the $13^{\text {th }}$ International Conference on Water-Rock Interaction, WRI-13. Guanajuato, 2010. - C. 387-390.

38. Казак Е.С., Поздняков С.П. Моделирование внутрипластового обезжелезивания подземных вод // Вестник Московского университета. Серия 4: Геология. - 2010. - № 6. - С. 68-74.

39. Millero F.J., Sotolongo S., Izaguirre M. The oxidation kinetics of Fe(II) in seawater // Geochim. et Cosmochim. Acta. - 1986. V. 51. - P. 793-801.

40. Hydrogenous mineral neoformations in Tomsk water intake facility from underground sources / E. Dutova, N. Nalivaiko, K. Kuzevanov, V., Pokrovsky I. Vologdina, D. Pokrovsky // IOP Conference Series: Earth and Environmental Science. - 2016.

41. Hydrogeochemical characteristics of water intakes from groundwater sources in Seversk / A.I. Karmalov, E.M. Dutova,
I.V. Vologdina, D.S. Pokrovsky, V.D. Pokrovskiy, K.K. Kuzevanov // IOP Conference Series: Earth and Environmental Science. 2016.

42. Природно-техногенные минеральные новообразования на водозаборах Томской области / И.В. Вологдина, Е.М. Дутова, Д.С. Покровский, В.Д. Покровский, И.В. Радюк // Вестник Санкт-Петербургского университета. Серия 7. Геология. География. - 2015. - № 3. - С. 58-72.

43. Утилизация отходов водоподготовки станций обезжелезивания / Н.Т. Усова, О.Д. Лукашевич, Л.В. Герб, О.Ю. Гончаров // Водоочистка. - 2012. - № 2. - С. 33-40.

44. Органические примеси в природных водах в районе г. Стрежевого / Ю.П. Туров, И.Д. Пирогова, М.Ю. Гузняева, Н.А. Ермашова // Водные ресурсы. - 1998. - Т. 25. - № 4. - С. 455-461.

Поступила 14.07.2019 2.

\section{Информация об авторах}

Дутова E.M., доктор геолого-минералогических наук, профессор отделения геологии Инженерной школы природных ресурсов Национального исследовательского Томского политехнического университета.

$\boldsymbol{K}$ узеванов $\boldsymbol{K}$.И., кандидат геолого-минералогических наук, доцент отделения геологии Инженерной школы природных ресурсов Национального исследовательского Томского политехнического университета.

$\boldsymbol{K} \boldsymbol{y} е в а н о в ~ \boldsymbol{K} . \boldsymbol{K}$., ассистент отделения геологии Инженерной школы природных ресурсов Национального исследовательского Томского политехнического университета. 
UDC 556.314

\title{
HYDRODYNAMIC JUSTIFICATION OF CHANGES IN HYDROGEOCHEMICAL CONDITIONS OF STREZHEVOY UNDERGROUND WATER FIELD (TOMSK REGION)
}

\author{
Ekaterina M. Dutova', \\ dutova@tpu.ru \\ Konstantin I. Kuzevanov', \\ kki@tpu.ru \\ Konstantin K. Kuzevanov' ${ }^{1}$, \\ kuzevanovkk@tpu.ru \\ ${ }^{1}$ National Research Tomsk Polytechnic University, \\ 30, Lenin Avenue, Tomsk, 634050, Russia.
}

\begin{abstract}
The research is relevant due to the need for studying the current condition of underground waters used as water supplies and analyzing the problems related to the change in chemical composition of underground waters caused by operation. These changes depend both on natural landscape and climatic and hydrogeochemical zonality, and on water intake operation mode. The enrichment of underground waters with iron due to regional features of geochemical conditions leads to inevitable application of water treatment which effectiveness can be significantly changed under the influence of water selection.

The main aim of the research is to estimate the potential impact of hydrodynamic conditions under the influence of long operation of large water intake on the changes in the quality of underground waters of the operated field.

Methods. The local monitoring of operating water intake has been conducted for a long period of time for solving operational investigation tasks on the operating field of underground waters. The analysis is based on the results of this monitoring. We have generalized observation data on the position of static levels. The materials of a hydrogeochemical approbation were used for studying the changes in chemical composition of underground waters. Such approbations are carried out regularly according to the regulations of regime observations. The overflowing between aquifers is assessed quantitatively by means of numerical hydrodynamic modeling.

Results. The analysis of monitoring results has shown that in the course of intensive operation of underground waters the favorable conditions for accumulating iron in the dissolved and hard-to-recovered form arise. The formation of complex organomineral iron compounds contributes to favourable conditions as such compounds are poorly manageable to removal during standard water treatment on the basis of aeration. We consider the changes in geochemical condition in the filter areas of operational wells to be the main reason for these anthropogenic processes. The changes in geochemical composition are caused by rising acid waters which have high concentration of organic compounds.
\end{abstract}

\section{Key words:}

Underground water field, chemical composition, monitoring underground waters,

changes in level and hydrogeochemical modes, hydrodynamic modeling of filtration processes.

\section{REFERENCES}

1. Gaev A.Ya., Savilova E.B. Ob obespechenii ekologicheskoy bezopasnosti vodozaborov hozyaystvenno-pitevogo naznacheniya neftedobyvayushchikh rayonov orenburzhya [About ensuring environmental safety of water intakes of economic and drinking purpose of the oil-extracting Areas of Orenburg Oblasts]. Vestnik Rossiyskogo universiteta druzhby narodov. Seriya: Ekologiya i bezopasnost zhiznedeyatelnosti, 2017, vol. 25, no. 2, pp. 294-305.

2. Gaev A.Ya., Alferov I.N., Kilin Yu.A., Kudelina I.V. 0 probleme pitevykh vod na urbanizirovannykh territoriyakh [On the problem of potable waters in the urbanized territories]. Ekologiches kie problemy promyshlennykh gorodov. Sbornik nauchnykh trudov po materialam 7 Vserossiyskoy nauchno-prakticheskoy konferentsii s mezhdunarodnym uchastiem [Environmental problems of the industrial cities. The collection of scientific works on materials of the $7^{\text {th }}$ All-Russian scientific and practical conference with the international participation]. 2015, pp. 259-263.

3. Pokrovskiy D.S., Dutova E.M. Balobanenko A.A., Pokrovskiy V.D., Rekhtin A.F. Hydrogeoecological conditions of water supply of the population of the South of the Siberian region. Vestnik Tomskogo gosudarstvennogo universiteta, 2014, no. 384, pp. 189-197. In Rus.

4. Gaev A.Ya., Kudelina I.V., Leonteva T.V., Alferov I.N., Savilova E.B. Problems of water, health and safety of residents of Oren- burg in the long term. Bulletin of the Volga university of V.N.Tatishchev, 2013, vol. 1, no. 4 (14), pp. 20-24. In Rus.

5. Kraynov S.R., Ryzhenko B.N., Shvets V.M. Geokhimiya podzemnykh vod [Geochemistry of underground waters]. Moscow, Tsentr LITNefteGaz Publ., 2012. $672 \mathrm{p}$.

6. Kraynov S.R., Shvets V.M. Geokhimiya podzemnykh vod khozyaystvenno-pitevogo naznacheniya [Geochemistry of underground waters of economic and drinking appointment]. Moscow, Nedra Publ., 1987. 237 p.

7. Fi T.H., Strokova L.A. Classification of soil types for Hanoi (Vietnam) when studying land subsidence at groundwater extraction. Bulletin of the Tomsk Polytechnic University. Geo Assets Engineering, 2017, vol. 328, no. 4, pp. 6-15. In Rus.

8. Fi T.H., Strokova L.A. Otsenka i prognoz osedaniya zemnoy poverkhnosti v rezultate izvlecheniya podzemnykh vod v gorode Hanoy (Vetnam) [Assessment and forecast of land surface sedimentation as a result of extraction of underground waters in the city of Hanoi (Vietnam)]. Geoekologiya. Inzhenernaya geologiya, gidrogeologiya, geokriologiya, 2014, no. 2, pp. 169-178.

9. Paufler S., Grischek T., Feller J., Herlitzius J., Kulakov V.V. Manganese release linked to carbonate dissolution during the start-up phase of a subsurface iron removal well in Khabarovsk, Russia. The science of the total environment, 2019, vol. 650 , pp. 1722-1733. 
10. Mi Lin, Asim Biswas, Elena M. Bennett. Identifying hotspots and representative monitoring area of groundwater changes with time stability analysis. Sience of The Total Environment, 2019, vol. 667 , pp. 419-426.

11. Samartsev V.N., Pozdnyakov S.P. Experience of calibration of geofiltrational model of a coastal water intake by sharing of the yielded experienced and filtrational works and results of monitoring during operation. Engineering geology, 2017, no. 3, pp. 36-43. In Rus.

12. Lekhov V.A., Pozdnyakov S.P., Bakshevskaya V.A. The experimental studying and numerical model operation of impact of diffusion on migration of pollution in the non-uniform sandy-argillaceous deposits. Engineering geology, 2017, no. 5, pp. 60-71. In Rus.

13. Muhammad Tousif Bhatti, Arif A.Anwar, Muhammad Aslam. Groundwater monitoring and management: Status and options in Pakistan. Computers and Electronics in Agriculture, 2017, vol. 135 , pp. 143-153.

14. Wang P., Pozdniakov S.P., Shestakov V.M. Optimum experimental design of a monitoring network for parameter identification at riverbank well fields. Journal of Hydrology, 2015, vol. 523, pp. 531-541.

15. Bocharov V.L., Savchenko 0.V. Gidrogeologicheskie usloviya i otsenka ekspluatatsionnykh zapasov podzemnykh vod basseyna reki Stanovaya Ryasa (Lipetskaya oblast) [Hydrogeological conditions and assessment of operational reserves of underground waters of a river basin of Stanovaya Cassock (Lipetsk region)]. Vestnik Voronezhskogo gosudarstvennogo universiteta. Seriya: Geologiya, 2015, no. 2, pp. 104-108.

16. Wang P., Yu J., Liu C., Pozdniakov S.P., Grinevsky S.0. Shallow groundwater dynamics and its driving forces in extremely arid areas: a case study of the lower heihe river in northwestern China. Hydrological Processes, 2014, vol. 28, no. 3, pp. 1539-1553.

17. Bocharov V.L., Strogonova L.N., Ovchinnikova E.S. Problemy izucheniya i ispolzovaniya resursov podzemnykh pitevykh vod Voronezhskoy oblasti [Problems of studying and using resources of underground potable waters of the Voronezh region]. Vestnik Voronezhskogo gosudarstvennogo universiteta. Seriya: Geologiya, 2010, no. 1, pp. 243-251.

18. McLean M.I., Evers L., Bowman A.W., Bonte M., Jones W.R. Statistical modelling of groundwater contamination monitoring data: A comparison of spatial and spatiotemporal methods. Science of The Total Environment, 2019, vol. 652, pp. 1339-1346.

19. Ayvaz M.T., Elçi A. Identification of the optimum groundwater quality monitoring network using a genetic algorithm based optimization approach. Journal of Hydrology, 2018, vol. 563, pp. 1078-1091.

20. P Jamin., Brouyère S. Monitoring transient groundwater fluxes using the Finite Volume Point Dilution Method. Journal of Contaminant Hydrology, 2018, vol. 218, pp. 10-18.

21. Bricker S.H., Banks V.J., Galik G., Tapete D., Jones R. Accounting for groundwater in future city visions. Land Use Policy, 2017, vol. 69, pp. 618-630.

22. Balobanenko A.A., L'Gotin V., Dutova E.M., Nikitenkov A.N., Raduk I.V., Pokrovsky D.S. Geochemical groundwater peculiarities of paleogene sediments in the Western Siberia artesian basin. IOP Conference Series: Earth and Environmental Science. 2016.

23. Dutova E.M., Pokrovskiy D.S., Parnachev V.P., Pokrovskiy V.D. Geochemical features of underground waters of economic and drinking purpose of the Republic of Khakassia. Bulletin of the Tomsk state university, 2015, no. 394, pp. 239-249. In Rus.

24. Bocharov V.L., Seleznev K.A. Geohimiya stronciya v podzemnyh vodah v yugo-zapadnoj kraevoj chasti moskovskogo artezianskogo bassejna (Orlovskaya oblast') [Strontium geochemistry in underground waters in a southwest regional part of the Moscow artesian basin (Oryol region)]. Vestnik Voronezhskogo gosudarstvennogo universiteta. Seriya: Geologiya, 2012, no. 2, pp. 179-189.
25. Kazak E., Pozdniakov S., Muromec N. Field study and iron reactive simulation in riverbank water supply well fields. IAHSAISH Publication GQ10: Groundwater Quality Management in a Rapidly Changing World. Proceedings of the seventh International GroundWater Quality Conference. - Zurich, Switzerland, 2011, pp. 419-422.

26. Lekhov A.V., Shvarov Yu.V. Rost mineralizatsii ekspluatiruemykh podzemnykh vod pri nalichii pirita v pokrovnykh otlozheniyakh [Height of a mineralization of the operated underground waters in the presence of pyrite in integumentary deposits]. Geoekologiya. Inzhenernaya geologiya. Gidrogeologiya. Geokriologiya, 2002, no. 4, pp. 316-325.

27. Ėerník M., Nosek J., Filip J., Hrabal J., Elliott D.W., Zbořil R. Electric-field enhanced reactivity and migration of iron nanoparticles with implications for groundwater treatment technologies: Proof of concept. Water Research, 2019, vol. 154, pp. 361-369.

28. Dobosy P., Vizsolyi C.É., Varga I., Varga J., Láng G., Záray G. Comparative study of ferrate and thermally activated persulfate treatments for removal of mono- and dichlorobenzenes from groundwater. Microchemical Journal, 2018, vol. 136, pp. 61-66.

29. Sharma S.K., Petrusevski B., Schippers J.C. Biological iron removal from groundwater. AQUA, 2005, vol. 54, no. 4, pp. 239-247.

30. Appelo C.A.J., Drijver B., Hekkenberg R., De Jonge M. Modeling in situ iron removal from ground water. Ground water, 1999, vol. 37, no. 6, pp. 811-817.

31. Trufanov A.I. Formirovanie zhelezistykh podzemnykh vod [Formation of ferruterous underground waters]. Moscow, Stroyizdat Publ., 1987. 133 p.

32. Sung W., Morgan J.J. Kinetics and product of ferrous iron oxygenation in aqueous systems. American Chem. Soc., 1980, vol. 14 , pp. 561-568.

33. Khushboo Chaudhary, Pankaj Kumar Saraswat, Suphiya Khan. Improvement in fluoride remediation technology using GIS based mapping of fluoride contaminated groundwater and microbe assisted phytoremediation. Ecotoxicology and Environmental Safety, 2019, vol. 168, pp. 164-176.

34. Sudipta Ghosh (Nath), Anupam Debsarkar, Amit Dutta. Technology alternatives for decontamination of arsenic-rich groundwater - a critical review. Environmental Technology \& Innovation, 2019, vol. 13, pp. 277-303.

35. Poi G., Shahsavari E., Aburto-Medina A., Mok P.Ch., Ball A.S. Large scale treatment of total petroleum-hydrocarbon contaminated groundwater using bioaugmentation. Journal of Environmental Management, 2018, vol. 214, pp. 157-163.

36. Kulakov V.V. Water treatment of potable waters in an aquifer on the Tungus water intake of sub-standard underground waters in Khabarovsk. Water management of Russia: problems, technologies, management, 2016, no. 2, pp. 87-97. In Rus.

37. Kazak E., Pozdniakov S., Kazak A. Sensitivity of model of ferrous iron oxidation by dissolved oxygen in the groundwater system. Water-Rock Interaction. Proc. of the $13^{\text {th }}$ International Conference on Water-Rock Interaction, WRI-13. Guanajuato, 2010. pp. 387-390.

38. Kazak E.S., Pozdnyakov S.P. Model operation of intra reservoir deferrization of underground waters. Bulletin of the Moscow university. Series 4: Geology, 2010, no. 6, pp. 68-74. In Rus.

39. Millero F.J., Sotolongo S., Izaguirre M. The oxidation kinetics of Fe(II) in seawater. Geochim. et Cosmochim. Acta, 1986, vol. 51, pp. 793-801.

40. Dutova E., Nalivaiko N., Kuzevanov K., Pokrovsky V., Vologdina I., Pokrovsky D. Hydrogenous mineral neoformations in Tomsk water intake facility from underground sources. IOP Conference Series: Earth and Environmental Science, 2016.

41. Karmalov A.I., Dutova E.M., Vologdina I.V., Pokrovsky D.S., Pokrovskiy V.D., Kuzevanov K.K. Hydrogeochemical characteristics of water intakes from groundwater sources in Seversk. IOP Conference Series: Earth and Environmental Science, 2016. 
42. Vologdina I.V., Dutova E.M., Pokrovskiy D.S., Pokrovskiy V.D., Radyuk I.V. Naturally technogenic mineral new growths on water intakes of the Tomsk region. Bulletin of the St. Petersburg university. Series 7. Geology. Geography, 2015, no. 3, pp. 58-72. In Rus.

43. Usova N.T., Lukashevich 0.D., Gerb L.V., Goncharov 0.Yu. Salvage of water treatment of stations of deferrization. Water purification, 2012, no. 2, pp. 33-40. In Rus.
44. Turov Yu.P., Pirogova I.D., Guznyaeva M.Yu., Ermashova N.A. Organicheskie primesi v prirodnykh vodakh v rayone g. Strezhevogo [Organic impurity in natural waters near Strezhevoy]. Vodnye resursy, 1998, vol. 25, no. 4, pp. 455-461.

Received: 17 July 2019.

\section{Information about the authors}

Ekaterina M. Dutova, Dr. Sc., professor, National Research Tomsk Polytechnic University.

Konstantin I. Kuzevanov, Cand Sc., associate professor, National Research Tomsk Polytechnic University.

Konstantin K. Kuzevanov, assistant, National Research Tomsk Polytechnic University. 